\title{
Why Do Consumers Trust Online Travel Websites? Drivers and Outcomes of Consumer Trust toward Online Travel Websites
}

Journal of Travel Research

$1-23$

(C) The Author(s) 2016

Reprints and permissions:

sagepub.com/journalsPermissions.nav DOI: $10.1|77 / 00472875| 6643 \mid 85$ jtr.sagepub.com

(S)SAGE

\author{
Gomaa M. Agag ${ }^{1,2}$ and Ahmed A. El-Masry ${ }^{1,3}$
}

\begin{abstract}
Egypt is currently one of the leading nations especially in the Middle East region with a well-established e-commerce environment and advanced IT infrastructure, but rapid growth of e-commerce will soon occur in other nations with similar consumption patterns. This study tests a model of antecedents (consumer experience, propensity to trust, reputation, perceived website size, ease of use, perceived usefulness, and website quality) and consequences of consumers' trust toward online travel websites. Trust is expected to predict consumer attitude, perceived risk, and intention to purchase travel online. Data of I,43I users of online travel websites were selected from the Supreme Council of Universities Database-Egypt (SCU) and analyzed through structural equation modeling. The findings show that all the aforementioned factors with the exception of consumer experience influence consumer trust toward online travel websites. Trust influences consumers' attitude, perceived risk, and intention to purchase travel online.
\end{abstract}

\section{Keywords}

intentions to purchase, online travel shopping, online trust, attitude, perceived risk

\section{Introduction}

The rapid development of information and communication technology (ICT) has largely changed the hospitality and tourism industries (Ho and Lee 2007; Ip, Law, and Lee 2011). Operations in hospitality and tourism have been significantly influenced by the advent of the Internet (Amaro and Duarte 2015; Gregori, Daniele, and Altinay 2014). The Internet is an effective marketing tool that facilitates information communication between sellers and customers (Buhalis and Law 2008). Thus, websites have become a platform for promoting products and services and another channel to generate revenue by attracting more customers (Chiou, Lin, and Perng 2010). With the rapid development and the increasing use of websites for information seeking and electronic commerce (e-commerce), trust has become a crucial factor in attracting customers (Beldad, de Jong, and Steehouder 2010). Internet has come as a new way of communication and selling for travel companies (Law and Wong 2003; Llach, Mariomon, and Alonso-Almeida 2013). In recent years, Egypt travel companies have faced massive challenges because of the changing character of the travel industry. For decades, hotels sector, airlines, and cruise lines industry had been dependent on intermediaries to sell their products to consumers. Internet as a new distribution channel will help travel providers to reach consumers directly and help travel providers to save money (Zhou 2004). Furthermore, the emergence of the Internet brought lower prices and time savings for consumers (Heung 2003).

The Internet is now a paramount distribution channel for travel companies (Lee and Morrison 2010). Travel business on the Internet accounts for 15 per cent of overall travel sales (US Census Bureau 2003). A forecast from the Market Intelligence Centre (MIC) (2009) reported that the online travel product category is the Internet's largest commercial area (48.9\%), generating a worldwide revenue more than 446 billion U.S. dollars (USD) in 2014. Sales of online travel worldwide grew 10\% between 2011 and 2014, and predictions until 2016 have shown that sales of online travel worldwide will grow at $8 \%$ yearly (Statista 2015).

\footnotetext{
'Plymouth Business School, Plymouth, Devon, United Kingdom

${ }^{2}$ Sadat City University, Sadat City, Menofia, Egypt

${ }^{3}$ Mansoura University, Mansoura, Dakahlia, Egypt \& Umm AIQura

University, Makkah, Saudi Arabia

Corresponding Author:

Ahmed A. El-Masry, Plymouth Business School, Drake Circus, Plymouth, Devon PL4 8AA, United Kingdom.

Email: ahmed.el-masry@plymouth.ac.uk
} 
A survey research reveals that the success of online shopping is determined mostly by consumer intentions to purchase (Park 2010). Unlike Internet consumers in Egypt and other emerging economies, however, Egyptian consumers are well known for fickle consumption patterns and lack of e-commerce trust, both of which pose major challenges to online shopping businesses (El-Ansary and Roushdy 2013).

E-commerce can increase the value of an Internet network in many respects but there are still some obstacles to overcome. First, the problems related to fraud on the internet are increasing every year. Second, the problems caused by spyware and other security vulnerabilities make consumers feel worried about their information provided on this network (Wang and Lin 2008). To avoid these uncertainties, some online shoppers are more inclined to buy from traditional stores (Moyano, Fernandez-Gago, and Lopez 2012). Moreover, lack of touch and feel in online shopping can also lead to hesitation among the shoppers. They can feel more risk when interacting with online stores than traditional ones (Gefen and Straub 2003). In order to reduce the possibility of interaction with ineligible vendors, online shoppers need to rely on their experience and other evidences to determine which websites can be trusted (Gefen and Straub 2003; Moyano, Fernandez-Gago, and Lopez 2012; Kim et al. 2005). Trust, therefore, serves as a foundation for initial relationship and being more important to maintain a long-term relationship for e-commerce success (Chen and Barnes 2007; Gefen and Straub 2003; Kim et al. 2005; Moyano, FernandezGago, and Lopez 2012; Kim, Ferrin, and Rao 2008; Ren and Hassan 2008; Yaobin and Tao 2007: Kim, Lee, Chung, and Kim 2014).

Customer trust is an essential factor of e-commerce, and understanding its drivers and outcomes is a main concern for the following reasons. First, the drivers of trust enable us to know the relative importance of aspects influencing trust. Understanding these variables would play a crucial role in devising suitable measures to facilitate trust. Second, the outcomes of trust enable us to better understand the importance of trust and its influence on online buying behavior.

Numerous studies have attempted to examine trust as a critical determinant of consumer intentions to purchase in e-commerce (e.g., Flavian, Guinalíu, and Gurrea 2006; Jarvenpaa, Tractinsky, and Vitale 2000; Yoon 2002; Lee and Turban 2006; Pavlou and Fygenson 2006; Hsu, Chuang, and Cheng-Se 2014). However, little attention has been paid to trust toward online travel websites (Ayeh, Au, and Law 2013a, 2013b; Yoo and Gretzel 2009; Filieri 2015) and whether trust has any effect on travel customer behavior. The questions that arise are, Why do consumers trust online travel websites? Does trust in online travel websites affect consumer attitude and intentions to purchase from these websites? The present research attempts to provide an answer to these questions. Such an integrated approach to examine the drivers and outcomes of trust is also lacking in the studies of Egyptian online travel companies. Teo and Liu (2007) noted that most of the research on consumer trust focuses on consumers in English-speaking countries and newly industrialized countries. Law, Leung, and Buhalis (2009) also noted that relationship marketing research in the tourism and hospitality industry focuses mainly on the supplier marketing activities of firms, and less attention has been paid to the consumer side of the exchange process. Research addressing online travel shopping presents contradictory results and is typically fragmented (Amaro and Duarte 2013).

This research adopts a distinctive way to analyze the factors that influence consumers' trust toward online travel websites and the influence of trust on consumer attitude, perceived risk, and intentions to purchase travel online, by proposing and empirically testing an integrated model, with contributions from well-grounded theories, namely, the technology acceptance model (TAM) (Davis 1986), Beldad, de Jong, and Steehouder's (2010) model, and the theory of reasoned action (TRA) (Fishbein and Ajzen 1975), contributing to the current literature since, to the best of knowledge, this has not been done in any other study. Therefore, the current study aims to contribute the following to the literature of tourism and hospitality: (1) identify the determinants that affect consumers' trust toward online travel websites; (2) by integrating the TAM, TRA, and Beldad, de Jong, and Steehouder's (2010) model, this study helps to understand consumers' trust toward online travel websites; (3) investigate the effect of trust on consumer attitude, perceived risk, and intentions to purchase travel online. The findings will help online travel companies' managers to evolve strategies that enhance consumers' trust toward online travel websites; consequently, attitude and intentions to purchase travel online.

Our study is organized as follows: the next section represents literature pertaining to the study variables and theories as well as the hypotheses development. Then we demonstrate our data collection and measures operationalization. Finally, study results, discussion, and managerial implications have been explained as well as demonstrating the limitations and future research.

\section{Tourism in Egypt: Brief Background}

Egypt, although often considered to be Middle East, is located in Northern Africa, bordering the Mediterranean Sea, between Libya and the Gaza Strip, and the Red Sea north of Sudan, and includes the Asian Sinai Peninsula. Egypt is part of the Mediterranean basin, the world's top destination area, which attracts one out of every three tourists traveling in the world (Morakabati 2007). Tourism is one of the most important parts of Egypt's economy. At its peak in 2013 the sector employed about $12.6 \%$ of Egypt's workforce, serving approximately 14.7 million visitors, and providing revenues of nearly \$19 billion (Egyptian Ministry of Tourism 2014). Tourism is the country's second biggest source of income after the revenue received from the Suez Canal and accounted 
for $11.3 \%$ of GDP and $14.4 \%$ of foreign currency revenues (Egyptian Ministry of Tourism 2014).

The main attraction for tourists to Egypt are the site of ancient Egypt, Cairo, and its environs, Luxor, Karnak, Abu Simbel, temples and tombs along the Nile River, and the Mediterranean port city of Alexandria. However, the Egyptian tourism industry has actively promoted other destinations within Egypt, including Hurghada on the Red Sea, the Sinai Peninsula, and parts of the western desert. The completion of Israel's removal from Sinai in 1982 led to considerable private and government tourist investment, which facilitated the development and establishment of several high-quality tourism resorts in the Sinai, which are popular among tourists from Europe and neighboring Israel (Beirmann 2003).

The Egyptian economy depends mainly on agriculture, media, Suez Canal, tourism, the transferred income of more than 5 million Egyptians working abroad (mainly in Saudi Arabia, the Gulf area, and Europe) and petroleum and gas exports (El-Gohary 2012). In the last 30 years, the Egyptian government has started reforming the highly centralized economy from the sixties and med seventies era into a totally market liberalization economy. But regardless of that, the high level of political, social, and economic corruption within the country did not allow any chance of improving the country poor economic performance. As a result, the people of Egypt turned against the Hosni Mubarak regime and got rid of his corrupted regime through the 25th of January 2011 revolution. Although the revolution was demanded and conducted by the people, it led to major chaos in the whole country, which badly affected all sectors, including the tourism and travel sector. The industry has been losing \$25 million per day since the 1st of February 2011 (El-Gohary 2012). Building online trust by Egyptian travel organizations can be a very important tool in solving the current problems associated with Egyptian travel industry as a result of the political unrest not only in Egypt but also in the Middle East.

\section{Research Model and Hypotheses}

In traditional commerce, the trust-building process is affected by the characteristics of customers, salespersons, the company, and interactions between the two parties involved. This is also true in the context of electronic commerce. Numerous studies have identified several drivers of trust, and most of these studies concentrated on transacting websites (Beldad, de Jong, and Steehouder 2010). Kim, Ferrin, and Rao (2008) conceptualized the key antecedents of consumer trust into four groups: cognition-based, affect-based, experiencebased, and personality-oriented antecedents. The cognitionbased trust antecedents are the antecedents that relate to the capability that shoppers perceive the target website (e.g., privacy concern, security protection, system reliability, information quality). The affect-based trust antecedents are regarded as indirect interactions from other parties (e.g., reputation, preferences of third-party seals, word of mouth, social feedback). The experience-based trust antecedents are associated with shopper experience (e.g., familiarity, Internet experience, e-commerce experience). And lastly, the personality-oriented trust antecedents are related to personal characteristics (e.g., disposition to trust, shopping style).

Beldad, de Jong, and Steehouder (2010) classified the antecedents of trust into three main categories: companybased antecedents, like company reputation; consumer-based antecedents, for instance, consumer experience with the technology; and website-based antecedents, for instance the information quality used by the website.

This study adapts Beldad, de Jong, and Steehouder's (2010) framework in order to investigate the drivers of trust toward online travel websites in the travel and tourism industry. Beldad, de Jong, and Steehouder's (2010) framework has been adapted in this study because it is an online trust-building framework that suits both profitable and nonprofitable firms; furthermore, it has not yet received empirical validation for online travel websites, and includes a number of links that have not been tested in a single model, which increases the originality of the current study.

To summarize, the key antecedents of consumer trust have been conceptualized into three categories: consumerbased antecedents (e.g., Consumer experience and propensity to trust), company-based antecedents of trust (e.g., company reputation and perceived size), and website-based antecedents of trust (e.g., perceived ease of use, perceived usefulness, and website quality). Moreover, the current study also investigates the consequences of consumer trust toward online travel websites, for example, perceived risk, attitude, and intention to purchase travel online. Therefore, this study examines the influence of consumers' trusting beliefs on their attitudes to the online travel provider and their risk perception. Consumers' attitudes to the online travel provider and their perceived risk, in turn, affect their willingness to purchase travel online. The research model and hypotheses are shown in Figure 1

\section{Consumer-Based Trust Antecedents}

\section{Consumer Experience and Proficiency}

Beldad, de Jong, and Steehouder (2010) pointed out that the level of user experience in using online shopping is an important aspect to consider when examining the antecedents of trust. Aiken and Boush (2006) indicated that higher levels of experience lead to low levels of trust in online stores. An explanation is that consumers with high levels of experience have sufficient skills and knowledge of possibilities that things online may go wrong any time (Aiken and Boush 2006). Nevertheless, some studies found that levels of user experience influence consumers' propensity to trust the Internet, thus improving their trust in Internet-based transactions (Corbitt, Thanasankit, and Yi 2003). 


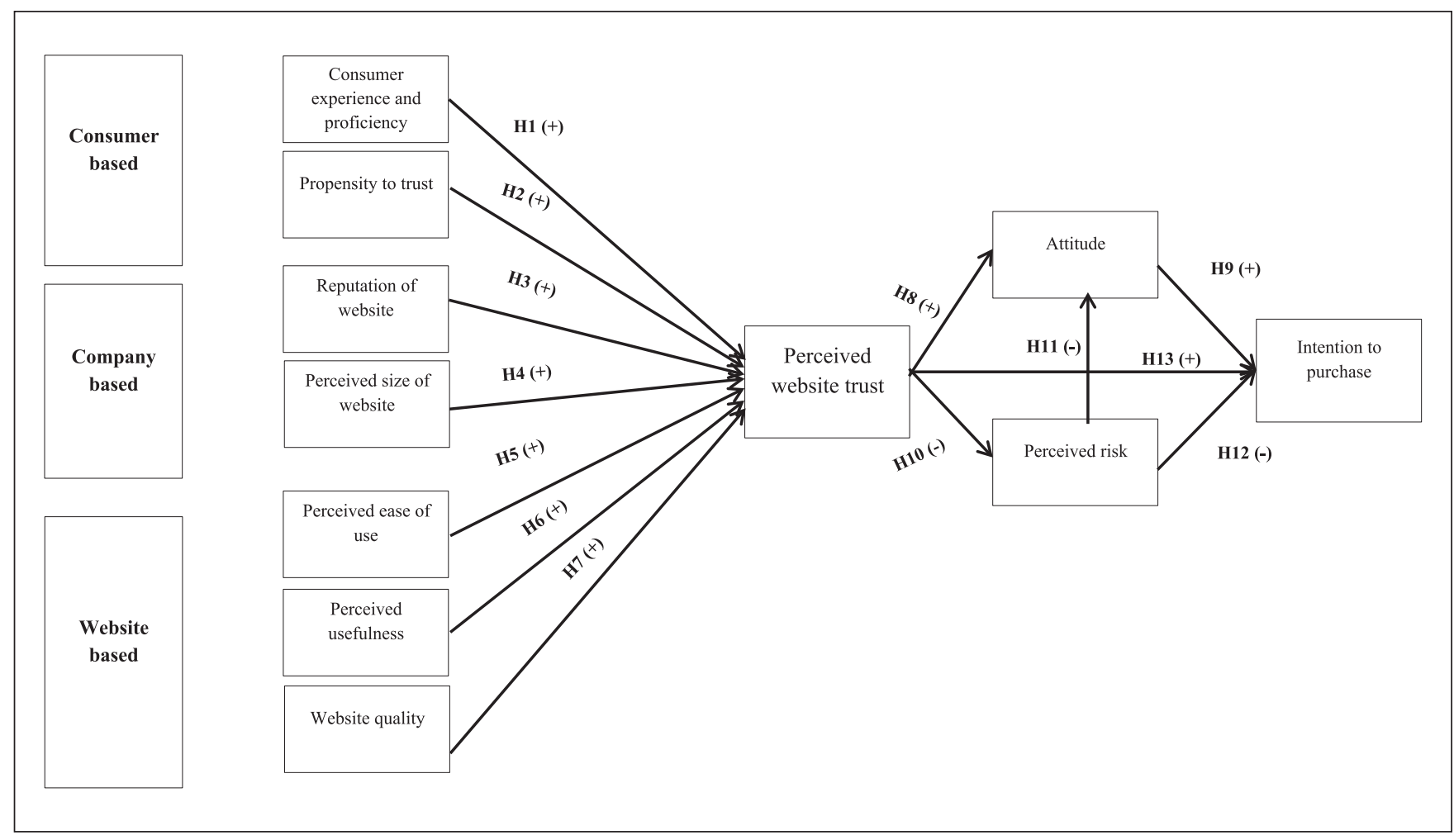

Figure I. Theoretical framework and hypotheses.

In the current study, it has been supposed that consumers who have sufficient experience with using online travel websites may feel more confident of not being deceived by unreliable websites. Experienced consumers may have sufficient knowledge and skills that enable them to spot unreliable websites. While first-time consumers have no knowledge about online travel websites and may be more cautious of online travel websites, they will not know how to distinguish between reliable and unreliable websites. In the online travel context, research has supported the positive and significant relationship between users' experience and trust toward online travel websites (Filieri 2015; Li-Ming and Wai 2013; Brakus et al. 2009) . Therefore, in the travel sector, the following hypothesis has been proposed.

Hypothesis 1: Consumers' experience with using online travel websites positively influences trust toward online travel websites.

\section{Propensity to Trust}

Propensity to trust plays an important role in economic transactions because it decreases the perceived risk (Humphrey and Schmitz 1998; Mukherjee and Nath 2007). This is especially true in the online context, where the consumers and sellers are physically separated. Some studies suggested that customers with low propensity to trust tend to have negative views when faced with risky situations
(Falcone, Singh, and Tan 2001; Graziano and Tobin 2002). Such propensity reduces their desire to try new things. On the other hand, customers with a high propensity to trust tend to have positive views and are willing to try new things (Graziano and Tobin 2002).

Mayer, Davis, and Schoorman (1995) pointed out that consumers vary in the amount of trust that they extend to their sellers. In the online context, some consumers are more likely to trust online service providers despite the limited information they have about them, while others need more information about their online service providers to form trusting beliefs (Salam et al. 2005). However, prior studies of the influence of individuals' propensity to trust on the formation of online trust present contradictory results (Beldad, de Jong, and Steehouder 2010).

Prior studies have found a direct and positive link between the propensity to trust and the formation of online trust (Gefen 2000; Teo and Liu 2007; Beldad, de Jong, and Steehouder 2010). The influence of propensity to trust is directly related to trust formation based on the system's trust attributes (Beldad, de Jong, and Steehouder 2010). In this study, it is argued that online travelers with a high propensity to trust perceive the risk to be less and therefore have more trust in online travel websites. Based on these arguments, the following hypothesis is posited:

Hypothesis 2: Propensity to trust positively influences consumers' trust toward online travel websites. 


\section{Company-Based Trust Antecedents}

\section{Company Reputation}

Company reputation has been suggested frequently as an important factor that contributes to customer trust. Some studies have pointed out that a positive company reputation results in a trusting relationship between the consumers and the company, while the existence of a negative company reputation results in a less trusting relationship (Smeltzer 1997; Beldad, de Jong, and Steehouder 2010; Herbig, Milewicz, and Golden 1994) and that when the company fails to fulfil the consumers' intentions, it results in the destruction of its reputation.

In the electronic commerce context, reputation can be defined in two ways. First, it can be seen as a collective measure of trustworthiness according to members' ratings in a community (Josang, Ismail, and Boyd 2007). Second, it can be a measure of a company's credibility, which results from the relationship among the company's promises and fulfilments (Casalo, Flavian, and Guinaliu 2007). Toms and Taves (2004) pointed out that a positive online company reputation can be formed through the assessment of a third party like the rating services on the website and indirectly through linking of the website. Vermeulen and Seegers (2009) revealed that consumers' feedback influence the reputation of the hotel and the attitudes toward it.

Numerous empirical studies revealed that the positive reputation of online service providers significantly influenced consumers' trust in online vendors (Chen 2006; Teo and Liu 2007; Gregori, Daniele, and Altinay 2014). Consumers who don't have an experience with an online service provider rely on the reputation of that online provider in order to assess the trustworthiness of that online service provider (Chen 2006; Koufaris and Hampton-Sosa 2004). Empirical evidence of the relationship between reputation and consumer trust has been provided by previous studies (e.g., Kim, Xu, and Koh 2004; Teo and Liu 2007; Hsu et al. 2014; Han, Nguyenb, and Lee 2015). Chen (2006) and de Ruyter, Wetzels, and Kleijnen (2001) have pointed out that online travelers are more likely to trust websites owned by well-known and well-respected companies. Thus, the authors propose the following hypothesis:

Hypothesis 3: Website reputation positively influences consumers' trust toward online travel websites.

\section{Perceived Size}

Doney and Cannon (1997) defined a website size as the market share and its overall size. Griffin and Hauser (1993) revealed that large market share and overall size of a firm suggest that it keeps the promises it makes to its customers and that many customers tend to trust it. Firms that do not keep their promises to the customers will not be able maintain their position (Doney and Cannon 1997). Chow and Holden (1997) pointed out that a large-sized firm can encourage consumers to trust it. Teo and Pian (2003) revealed that larger organizational size is also related to a more developed website that encourages transactions with customers. In the context of e-commerce, an e-vendor with a large size can reduce product risk and compensate consumers accordingly (Jarvenpaa, Tractinsky, and Vitale 2000). E-vendors' size positively influences consumers' trust toward it (Jarvenpaa, Tractinsky, and Vitale 2000). Consumers can deduce trustworthiness from a website size since larger website size means that the website can handle any failure and losses incurred during the transaction process and compensate the consumers (Beldad, de Jong, and Steehouder 2010; Jarvenpaa, Tractinsky, and Vitale 2000; Hsu et al. 2014). Furthermore, some studies have pointed out that vendor size is positively associated with customer trust in that vendor (Kim and Ahn 2006; Ku 2012; Hsu, Chuang, and Cheng-Se 2014). Hence, it follows that

Hypothesis 4: The perceived size of an online travel website positively influences consumers' trust toward online travel websites.

\section{Website-Based Trust Antecedents}

\section{Perceived Ease of Use}

According to the literature, numerous studies have applied various theoretical perspectives to explain and understand consumers' acceptance and use of new technology. Of these, the TAM considers the most effective approach to investigating consumer acceptance and use of technology-related applications (Ayeh 2015). The TAM, initially proposed by Davis (1986), postulates that individuals' perceptions about ease of use and usefulness are two cognitive factors that determine their acceptance of the information system. TAM has received substantial empirical support in explaining consumer acceptance of various types of technology, for example, technology-based services (Zhu and Chan 2014), smartphones (Joo and Sang 2013), and the new media (Workman 2014).

In tourism and hospitality context, numerous studies applied TAM to understand and explain consumer acceptance of new technology including hotel front office systems (Kim, Ferrin, and Rao 2008), consumer intention to shop travel online (Amaro and Duarte 2015 and Casaló, Flavián, and Guinaliu 2010), biometric systems adaption in hotels (Morosan 2012), and restaurant computing systems (Ham, Kim, and Forsythe 2008). The findings of these studies show that perceived ease of use and perceived usefulness are crucial determinants of consumer acceptance of new technology.

Perceived ease of use has been defined as "the degree to which a person believes that using a particular system would be free of effort" (Davis 1989, 320). In the current study, perceived ease of use is defined as the extent to which travelers 
believe that an online travel website is easy to use. Research has supported the positive and significant relationship between perceived ease of use and consumer trust (Gefen, Karahanna, and Straub 2003; Tung, Chang, and Chou 2008). Thus, the authors propose the following hypothesis:

Hypothesis 5: Perceived ease of use positively influences consumers' trust toward online travel websites.

\section{Perceived Usefulness}

Davis $(1989,320)$ conceptualized perceived usefulness as "the degree to which a person believes that using a particular system would enhance his or her job performance." In our study, perceived usefulness refers to the extent to which the consumer believes that using online travel websites improves his or her travel planning.

While some researchers Palvia (2009) proposed "perceived usefulness" as an antecedent to transaction intention based on TAM, to our knowledge, no existing study specified perceived usefulness as an antecedent to trust. As Gefen, Karahanna, and Straub (2003) suggested it would make more sense to postulate that perceived usefulness is a consequence, not an antecedent, of trust in an e-commerce firm. A business relationship developed based on trust provides a measure of subjective guarantee that the e-commerce firm will behave with good will and that the outcome of a transaction will be fair and favorable, and thus increase the benefits of transacting on the e-commerce website that consumers come to perceive as more useful (Gefen, Karahanna, and Straub 2003). In support of this notion, Agag and El-Masry (2016a, 2016b) found a significant path from perceived usefulness and consumer trust toward online travel community websites. Therefore, it is decided to rule out perceived usefulness as a trust antecedent from our model. Hence, the hypothesis:

Hypothesis 6: Perceived usefulness positively influences consumers' trust toward online travel websites.

\section{Website Quality}

A website is the main communication channel between customers and firms (Casalo, Flavián, and Guinalíu 2008), and therefore the website's quality plays a crucial role in the success of online commerce (Hsu, Chang, and Chuang 2015). Website quality is defined as "users' evaluation of whether a web site's features meet users' needs and reflect the overall excellence of the web site" Chang and Chen (2008, 821). DeLone and McLean (2003) pointed out that website quality includes three distinct dimensions: information quality, system quality, and service quality. Numerous studies have adopted DeLone and McLean's (2003) approach (e.g., Ho, Kuo, and Lin 2010; Cheng and Huang 2013; Liu and Zhang 2014).

In the current study, information quality refers to consumers' perceptions about the information quality, privacy, and security of an online travel website. Furthermore, the system quality of an online travel website refers to consumers' perceptions about website availability, adaptability, and response time. Finally, service quality describes consumers' perceptions about responsiveness, empathy, and assurance.

In the e-commerce field, prior studies have confirmed the positive link between website quality and consumer trust (McKnight et al. 2002). In the field of tourism and hospitality e-commerce, a significant and positive relationship between website quality and consumer trust is supported by Filieri (2015), Kim, Chung, and Lee (2011), and Wang et al. (2015). If an online travel website is perceived as secure and safe, eases customers' navigation, is responsive, empathic, and reassuring, the consumer will form a positive impression of the website, and which ultimately will be perceived as reliable. Accordingly, the following hypothesis has been posited:

Hypothesis 7: Website quality positively influences consumers' trust toward online travel websites.

\section{Consequences of Consumer Trust}

Trust is conceptualized as the subjective belief that the online provider will fulfil its transactional obligations, as those obligations are understood by the consumer (Kim, Ferrin, and Rao 2008). Notwithstanding the crucial role of trust in an online context, Kim, Chung, and Lee (2011) pointed out that there is a paucity of research on trust in the online context for tourism products. Trust in websites plays a paramount role in e-commerce because consumers are unlikely to shop online if they do not trust the website (Kim, Chung, and Lee 2011).

The main dependent variable of the model is consumer intentions to purchase travel online. This variable has been derived from the TRA, which postulates that behavioral intention is the main predictor of actual behavior (Fishbein and Ajzen 1975). Behavioral intentions have been used as a strong predictor of actual behavior in the online shopping context (Ajzen 2011; Lin 2007; Casaló, Flavián, and Guinaliu 2010). Furthermore, in the context of online travel shopping, behavioral intentions have been posited as the best predictor of actual behavior (Moital, Vaughan, and Edwards 2009; Amaro and Duarte 2015; Ponte, Carvajal-Trujill, and Escobar-Rodr 2015). Therefore, because of the difficulties regarding measuring consumers' real behavior, this study focuses on behavioral intentions as the best predictor of consumers' actual behavior.

\section{Consumer Trust, Attitude, and Intention to Purchase}

The TRA examines the relationships between attitudes, beliefs, intentions, and behaviors (Ajzen and Fishbein 1980). The theory emphasizes that consumers' intention is determined by their attitudes toward the behavior, and their 
attitudes are affected by their beliefs. The theory has been widely applied and accepted in many contexts and disciplines. Prior studies revealed that trust is significantly related to attitude, and attitude is significantly related to consumer intention (Chow and Holden 1997; Macintosh and Lockshin 1997). The TRA has also been applied as the theoretical base in some studies on trust formation (McKnight et al. 2002; Mcknight and Chervany 2001), especially in the e-commerce context (Teo and Liu 2007).

In the e-commerce field, several prior studies have confirmed the positive link between trust and the intentions to purchase online (Chiu, Huang, and Hui 2010; Gefen, Karahanna, and Straub 2003; Kim, Xu, and Gupta 2012). In the field of tourism and e-commerce, a significant and positive relationship between trust and purchase intention is supported by a variety of studies (e.g., Bigne et al. 2010; Escobar-Rodríguez and Carvajal-Trujillo 2014; Kim, Chung, and Lee 2011; Sanz-Blas, Ruiz-Mafe, and Perez 2014; Amaro and Duarte 2015; Ponte, Carvajal-Trujill, and Escobar-Rodr 2015; Agag and El-Masry 2016a, 2016b).

Alsajjan and Dennis (2010) found that trust influences consumer attitude and the intention to engage in a behavior. Consumers who trust in online service provider websites will have a positive attitude toward this online service provider's website and more likely to repurchase. In support of this notion, Amaro and Duarte (2015), Ashraf, Thongpapanl, and Auh (2014), and Ayeh, Au, and Law (2013b) found a significant path from trust to customer attitude and repurchase intentions. Hence, the following hypotheses are proposed.

Hypothesis 8: Consumer trust toward online travel website positively influences their attitude toward this website.

Hypothesis 9: Consumer attitude toward online travel website positively influences their intention to purchase from this website.

\section{Consumer Trust, Risk Perception, Attitude, and Intention to Purchase}

Consumers' perceived risks associated with online shopping have received limited attention despite their implications for e-commerce (Amaro and Duarte 2015). Jarvenpaa and Todd (1997) have deemed perceived risk to be a major obstacle to the future growth of e-commerce. The current study focuses on risks related to the Internet as a means for purchasing and not the travel online service itself. Therefore, perceived risk refers to the potential loss perceived by a customer in considering travel online shopping when compared to the purchase of travel offline.

Prior studies have evidenced a negative relationship between a consumers' perceived risk and their intentions to purchase of travel online (Jensen 2012; Kim, Kim, and Shin 2009; Chen et al. 2015; Yang 2012). Other research has found that trust negatively influences perceived risk (Kamarulzaman 2007; Amaro and Duarte 2015). Teo and Liu (2007) pointed out that trust can reduce the consumer's perception about risk associated with online service providers' opportunistic behavior.

The TRA asserts that consumers' perceived risk has a negative relationship with their attitudes toward the purchasing behavior. In an online travel context, where the transactions involve considerable risk and uncertainty, consumers' attitudes toward online travel websites tend to be less positive. Prior studies pointed out that perceived risk has a negative association with attitude toward online travel websites (Amaro and Duarte 2015; Jensen 2012).

In the e-commerce field, several prior studies have confirmed the positive link between trust and the intentions to purchase online (Chiu, Huang, and Hui 2010; Gefen, Karahanna, and Straub 2003; Kim, Xu, and Gupta 2012). In the field of tourism and e-commerce, a significant and positive relationship between trust and purchase intention is supported by a variety of studies (e.g., Bigne et al. 2010; Escobar-Rodríguez and Carvajal-Trujillo 2014; Kim, Chung, and Lee 2011; Sanz-Blas, Ruiz-Mafe, and Perez 2014; Amaro and Duarte 2015; Ponte, Carvajal-Trujill, and Escobar-Rodr 2015). Therefore, in the travel sector, the following is proposed:

Hypothesis 10: Consumer trust toward online travel website negatively influences the perceived risk of online travel shopping.

Hypothesis 11: The perceived risk of online travel shopping negatively influences consumers' attitude toward online travel website.

Hypothesis 12: The perceived risk of online travel shopping negatively influences consumers' intention to purchase travel online.

Hypothesis 13: Consumer trust toward online travel website positively influences consumers' intention to purchase travel online.

\section{Methodology}

\section{Sampling and Data Collection}

A positivist research philosophy was utilized with a quantitative approach to validate the proposed framework, and quantitative data were collected using survey questionnaires to address different levels of the study. The target population of the current study comprises all consumers who had purchased travel products online at least once in the last one year (e.g., an airline ticket, a hotel accommodation, a car rental, a cruise reservation, transportation reservations, and a travel package). The travel consumers who participated in this study had recent experience in the use of online travel websites for tourism-related products and services (e.g., an airline ticket, a hotel accommodation, a car rental, a cruise 
reservation, transportation reservations, and a travel package), which was assessed in different ways: first, the e-mail sent to potential respondents clearly stated that only people with recent experiences with online travel websites could participate in this study; second, the respondents were asked to write the name of the website where they have made online purchases and indicate how frequently they used this website before. However, since there was no list of Internet shoppers across Egypt, it was impossible to select our sample from the population directly. Thus, convenience sampling was used to collect data (San Martín and Herrero 2012).

The first step in the process was to get permission from Egyptian tertiary institutions in order to send the surveys to their students. In total, 5 tertiary institutions out of 27 agreed for their students to participate in this study. These institutions were Cairo University, Alexandria University, Sadat City University, Assiut University, and the American university in Cairo. The second step involved universities sending an informed consent e-mail explaining the study purpose, with an attached URL hyperlink to all students. The final step was to send a follow-up e-mail to remind students to complete and submit the survey 1 week and then 1 month after the informed consent e-mail in order to achieve a higher response rate (Richardson 2009).

Egypt has been chosen to implement the empirical part of this research for a number of reasons. First, to the researcher's best knowledge, this is the first research to be conducted in Egypt on online travel in the tourism sector, in which no previous empirical or conceptual work exists. Thus, this research represents an empirical contribution in that regard. Second, studying a developing country like Egypt represents a valuable extension to online travel studies that have been primarily focused on developed countries. E-commerce is highly successful in developed countries in comparison with developing countries, where information and communications technology (ICT) application is still in its early stages (Aldhmour and Shannak 2009; Bhuasiri et al. 2012); this led to the digital divide between developed and developing countries (Aldhmour and Shannak 2009). This was obvious when revising the literature, which confirmed that ICT diffused rapidly in developed countries but slowly in developing countries, leading to an ICT gap or digital divide between developed and developing countries (Aladwani 2003), which explains why developing countries always are latecomers to ICT. Businesses in developing countries face different challenges from those in developed countries (Molla and Licker 2005) and it would be really useful to discover whether the same factors influence consumers' trust in online travel websites as in developed countries. Third, Egypt is one of the top countries worldwide in terms of the growth potential of tourism, and thus it is expected to make large benefits by investigating drivers and outcomes of consumers' trust toward online travel websites. It is therefore important to consider what factors can lead travelers in Egypt to trust online travel websites. Gaining knowledge of the drivers and outcomes of consumers' trust in online travel websites could provide valuable information that would help enhance the competitiveness of the tourism industry in Egypt.

Data were collected using a Web-based survey. The use of such a uniform data collection method helps to minimize social desirability bias and controls for response styles (de Leeuw 2008). Besides, online surveys have been applied successfully in recent hospitality and tourism research (e.g., Gardiner, King, and Grace 2012; Eid and El-Gohary 2015; Zhang, Wu, and Mattila 2016). Furthermore, an online method of distribution was appropriate for this study as it facilitated a national geographic dispersal of the survey (Aaker, Kumar, and Day 2007).

In July 2015, recruitment e-mails were sent directly to faculty members at the five tertiary institutions in Egypt asking students to complete the online survey. A screening question was formulated in the first section to identify eligible respondents; the screening question asked whether the respondent had made online purchases of travel products in the past 6 months. Positive answers enabled respondents to proceed with the survey. College students were chosen because they not only represent a vulnerable and significant Internet user but are also an important cohort, Generation Y, to online retailers (National Retail Federation 2007; Jai, Burns, and King 2013). They have the highest Internet usage of any other cohort, and their online buying and purchasing behavior is representative of technology-savvy users (Fox and Madden 2005; Larose and Rifon 2007; Jai, Burns, and King 2013). Student samples have often been used in online shopping research (e.g., Kim, Fiore, and Lee 2007; Ashraf, Thongpapanl, and Auh 2014; Jai, Burns, and King 2013; Elbeltagi and Agag 2016; Agag and El-Masry 2016b). This is justifiable as students have few troubles in using new technology and are computer literate (Ashraf, Thongpapanl, and Auh 2014). Students have actual online experiences and are potential consumers of electrical goods (Yoo and Donthu 2001), and their technological advances and innovativeness qualify them as a suitable sample for online shopping research (Yoo and Donthu 2001). The e-mail invitations provided respondents with information on the purpose of the study, the approximate time to fill out the questionnaire, and a banner with a hyperlink connecting to our web survey.

A pilot test was conducted to assess the validity and reliability of the research instrument. The instrument was given to a group of 50 postgraduate students at Sadat City University in Egypt who mentioned that they had used and were familiar with online travel websites. Their comments resulted in refinement of the instrument in terms of its length, format, readability, and clarity. Twenty online travel managers were also asked to review the questionnaire. This review resulted in elimination of a specific item measuring perceived risk. The exclusion of this item did not pose a major threat to construct validity, since there were three additional items assessing perceived risk. Some wording changes were also made. 
Table I. The Sampling Procedure.

\begin{tabular}{lc}
\hline Sampling Step & Responses \\
\hline $\begin{array}{l}\text { E-mail sent for screening of } \\
\text { potential respondents }\end{array}$ & 3,800 \\
Replied & 3,250 \\
Qualified & $\mathrm{I}, 860$ \\
$\begin{array}{l}\text { E-mail sent for actual survey } \\
\text { invitation }\end{array}$ & $\mathrm{I}, 860$ \\
Replied & \\
Qualified & $\mathrm{I}, 463$ \\
\hline
\end{tabular}

Table 2. The Sampling Profile for Online Shoppers $(N=3,250)$.

\begin{tabular}{llrc}
\hline Variable & \multicolumn{1}{c}{ Category } & $n$ & \% of Response \\
\hline Age & $18-29$ & 1,170 & 36 \\
& $30-39$ & 868 & 27 \\
& $40-49$ & 646 & 20 \\
& $50-59$ & 410 & 13 \\
Gender & Over 60 & 156 & 4 \\
& Male & 1,654 & 51 \\
Education & Female & 1,596 & 49 \\
& Bachelor's degree & 865 & 27 \\
& Diploma & 919 & 29 \\
& Master's or doctorate & 1,026 & 31 \\
Frequency of & Other & 440 & 13 \\
online travel & 3-6 times & 679 & 21 \\
shopping & 6-9 times & 984 & 30 \\
within a year & $>9$ times & 816 & 25 \\
& & 774 & 24 \\
\hline
\end{tabular}

The participants in this study were randomly selected from the Supreme Council of Universities Database-Egypt (SCU). The participants from the SCU were not self-selected but were recruited using probability sampling methods where e-mail addresses were randomly picked by a generated sampling system, similar to random-digit dialing (RDD).

The questionnaire was available online between July 20 and September 15, 2015. As shown in Table 1, the initial e-mails were sent to 3,800 respondents, randomly picked by the system from the SCU. Probability sampling takes place when the probability of the selection of each respondent is known. With this, statistical inferences on the chosen sample of Internet shoppers could be made in this study. The selected respondents from the SCU could represent the total population of Internet shoppers, and this approach also permits generalization. These e-mails were sent with a link to a simple multiple-choice screening question asking about the types of products that the respondents had purchased over the Internet in the last year. A total of 3,250 respondents replied to the question stating the various types of travel products they had purchased online at least once in the last one year (see Table 2). From this number, only 1,860 respondents indicated that they had purchased travel services online. This means that 1,860 respondents were qualified for the actual survey, which also indicates the sample size for the study. In the actual survey, e-mail invitations were sent to all 1,860 respondents, and a total of 1,463 responses were obtained. The total number of responses was large; hence, the complete case approach was used (Hair et al. 2010) and all responses with missing values (32) were eliminated. Therefore, a total of 1,431 responses were considered to be valid for further analyses. This actually meets the suggestion by Bartlett, Kotrlik, and Higgins (2010) and Barclay, Higgins, and Thompson (1995) that when determining the sample size for PLS estimation, 10 cases per predictor were used as a cut-off sample size. In our model, the most complex regression involved the number of paths to the trust construct, which was seven. Therefore, according to this rule, 70 responses would be necessary as the minimum sample size for our study. Since 1,431 cases were collected, the current research sample size is a very good and practically acceptable size for the use of PLS. Another test has been conducted using the following equation suggested by Westland (2010), $n \geq 50 r^{2}-450 r+1,100$, where $n$ is sample size and $r$ is the ratio of indicators to latent variables. Since 1,431 cases were collected, the current research sample size satisfies the lower sample size threshold for structural equation modeling (Westland 2010).

\section{Questionnaire and Measurements}

The questionnaire for the present study was divided into two main sections. The first section contained questions to measure each construct based on existing measures or adapted from similar scales. It should be noted that all constructs have a reflective measurement. The last section of the questionnaire consisted of questions regarding respondents' demographic characteristics, for example, gender, age, and education level. To prevent duplicate responses, the option to control and remove duplicate responses by IP was used. The research model has 11 constructs, each having items that are gauged by a Likert-type scale $(1=$ strongly disagree and $5=$ strongly agree).

The scale used to measure trust toward online travel websites was similar to a scale adopted in previous studies (Morgan and Hunt 1994; Kim, Chung, and Lee 2011; Corbitt, Thanasankit, and Yi 2003; Filieri 2015; Kim, Ferrin, and Rao 2008) and modified based on a pilot study. The scale used to measure consumers' experience with online travel websites was adapted from Smith, Menon, and Sivakumar (2005) and Filieri (2015). The measured scale of propensity to trust was generated based on related studies (Teo and Liu 2007; Cheung and Lee 2001; Bianchi and Andrews 2012). The variables of reputation and perceived size in this study were operationalized with three items each as suggested by Teo and Liu (2007), Doney and Cannon (1997), and Jarvenpaa, Tractinsky, and Vitale (2000). The variables of perceived ease of use and perceived usefulness in this study were operationalized with three items each as suggested by Davis (1989) scales and Cheng, Lam, and Yeung (2006), Moore 
and Benbasat (1991), and Castaneda, Munoz-Leiva, and Luque (2007). Perceived usefulness items reflected the consumer's belief that using online travel websites improved his or her travel planning. Perceived ease of use items reflected the ease of using online travel websites, while website quality was measured by a scale used in previous studies of online travel (Filieri 2015; Hsu et al. 2014; Teo, Srivastava, and Jiang 2009). Attitude toward online travel websites in this study was operationalized with three items adapted from Chen and Wells (1999) and Castaneda, Munoz-Leiva, and Luque (2007). For perceived risk, three items were adapted from Amaro and Duarte (2015) and Shim et al. (2001). Finally, intentions to purchase travel online were conceptualized as containing purchase intention and continued interaction. Intentions to purchase travel online were measured by four items borrowed from $\mathrm{Kim}, \mathrm{Xu}$, and Gupta (2012), Mukherjee and Nath (2007), Bigne et al. (2010), and Castaneda, Munoz-Leiva, and Luque (2007).

Structural equation modeling (SEM) has been selected over simple regression tools because it tests a series of dependence associations simultaneously (Hair et al. 2010). Partial least squares (PLS-SEM) were applied, and the Warp PLS 3.0 program was used to validate the measures and test the hypotheses. First, PLS minimizes the endogenous variables' residual variances, and it is also an appropriate technique to address multiple relationships at the same time (Hair, Ringle, and Sarstedt 2011; Henseler, Ringle, and Sinkovics 2009). Second, a PLS approach does not require a normal distribution, as opposed to covariance-based approaches, which requires a normal distribution (Henseler, Ringle, and Sarstedt 2012), Finally, PLS is also recommended for testing complex frameworks (e.g., multiple mediators) (Magnusson et al. 2013).

\section{Results}

\section{Descriptive Statistics}

A total of 1,431 respondents were surveyed online. Of these 1,431 participants, 920 were men $(64.0 \%)$ and 511 were women $(36.0 \%)$. The majority of respondents were aged between 18 and $29(41.0 \%)$ years, had postgraduate education (master's and doctorate) $(60.0 \%)$, and had engaged in online shopping between three and six times within the previous year $(62.0 \%)$. Although the percentage of participants with master's and doctorate is high $(60 \%$ of online travel product shopping population), it actually represents only $26 \%$ of the online shoppers. Table 3 shows the respondents' demographics.

The data show that for the most part, these respondents have made online purchases from well-known domestic travel websites, such as Egyptair.com (largest domestic airline), Almrsal.com (largest domestic accommodation and hotel), Cairo360.com (largest domestic transportation), Selaheltelmeez.com (domestic accommodation and hotel), and Agoda.com (domestic accommodation and hotel).
Respondents have also purchased from foreign travel websites predominantly at Booking.com and Tripadvisor.com. Furthermore, the most frequently purchased online travel products by respondents are hotel reservations $(41 \%)$, air flight tickets (29\%), transportation reservations (18\%), and a car rental $(12 \%)$.

\section{Model Assessment}

The evaluation of a conceptual framework using PLS analysis contains two steps. The first step includes the evaluation of the measurement (outer) model. The second step involves the evaluation of the structural (inner).

\section{Measurement Model}

Tests of normality were conducted to satisfy the criterion of multivariate normality, namely, skewness, kurtosis, and Mahalanobis distance statistics (Bagozzi and Yi 1988), for all the constructs (Table 7; see appendix). These indicated no departure from normality. The Cronbach's alpha reliability coefficient was calculated in order to assess the psychometric properties of the constructs (Nunnally and Bernstein 1994).

The first step in evaluating a research model is to present the measurement model results to examine the indicators of internal consistency reliability, convergent validity, and discriminant validity (Hair, Ringle, and Sarstedt 2011).

As shown in Table 4, Cronbach's alpha for all measures exceeds the recommended threshold value of 0.70 (Hair, Ringle, and Sarstedt 2011). Therefore, all measures are robust in terms of their reliability. Henseler, Ringle, and Sinkovics (2009) pointed out that composite reliability is more suitable for PLS-SEM. In our study, the composite reliabilities range from 0.84 to 0.98 , which are above the 0.70 cut-off point (Bagozzi and Yi 1988). Finally, all indicator loadings exceed the recommended threshold value of 0.60 (Henseler, Ringle, and Sinkovics 2009).

To assess convergent validity, according to Fornell and Larcker (1981), AVE was calculated for each construct in our proposed model (see Table 4). Since all constructs' AVE are above the 0.50 cut-off, the results support convergent validity.

Discriminant validity is considered in two steps. First, the Fornell and Larcker criterion is used to test whether the square root of a construct's AVE is higher than the correlations between it and any other construct within the model. As shown in Table 5, each construct shares more variance with its own block of indicators than with another latent variable. Second, the factor loading of an item on its associated construct should be greater than the loading of another nonconstruct item on that construct (Chin 2010). The results, presented in Table 6, indicate that all indicators loaded on their own construct more highly than on any other, supporting that the constructs are distinct.

In order to assess potential nonresponse bias, following the method proposed by Armstrong and Overton (1977), we 
Table 3. The Sampling Profile of Online Travel Products $(N=I, 43 I)$.

\begin{tabular}{|c|c|c|c|c|}
\hline Variable & Category & $n$ & $\begin{array}{l}\% \text { of Online Travel } \\
\text { Shoppers Response }\end{array}$ & $\begin{array}{c}\% \text { of Online Shoppers } \\
\text { Response }\end{array}$ \\
\hline \multirow[t]{5}{*}{ Age } & $18-29$ & 580 & 0.41 & 0.18 \\
\hline & $30-39$ & 350 & 0.24 & 0.11 \\
\hline & $40-49$ & 212 & 0.15 & 0.07 \\
\hline & $50-59$ & 160 & 0.11 & 0.05 \\
\hline & Over 60 & 129 & 0.09 & 0.04 \\
\hline \multirow[t]{2}{*}{ Gender } & Male & 920 & 0.64 & 0.28 \\
\hline & Female & 511 & 0.36 & 0.16 \\
\hline \multirow[t]{4}{*}{ Education } & Bachelor's degree & 480 & 0.34 & 0.15 \\
\hline & Diploma & 96 & 0.07 & 0.03 \\
\hline & Master's or doctorate & 855 & 0.60 & 0.26 \\
\hline & Other & 0 & - & - \\
\hline \multirow{4}{*}{$\begin{array}{l}\text { Frequency of } \\
\text { online travel } \\
\text { shopping within } \\
\text { a year }\end{array}$} & $<3$ times & 210 & 0.15 & 0.06 \\
\hline & $3-6$ times & 887 & 0.62 & 0.27 \\
\hline & $6-9$ times & 215 & 0.15 & 0.07 \\
\hline & $>9$ times & 119 & 0.08 & 0.04 \\
\hline
\end{tabular}

tested whether there were significant differences among the early and late respondents. A total of 550 respondents completed the survey during the early stage and 438 completed the survey during the late stage. The chi-square test did not reveal any significant differences between early and late respondents at the 5\% significance level. Therefore, the possibility of nonresponse bias was excluded.

A principal components factor analysis was conducted, and the results excluded the potential threat of common methods bias (Podsakoff et al. 2003). The first (largest) factor accounted for $36.42 \%$ (the variances explained ranges from $18.05 \%$ to $36.42 \%$ ), and no general factor accounted for more than $50 \%$ of variance, indicating that common method bias may not be a serious problem in the data set. In addition, following the method proposed by Liang et al. (2007), the results indicate that the substantive variance of indicators is 0.7 , the average method-based variance is 0.006 , and all the method factor loadings are not significant. Therefore, we may contend that common method bias may not be a serious problem in the data set.

Multicollinearity tests were performed because of the relatively high correlations among some of the constructs. All constructs had variance inflation factor (VIF) values less than 2.1, which is within the cut-off level of 3.0 (Hair, Ringle, and Sarstedt 2011).

\section{Structural Model Assessment}

Since the measurement model evaluation provided evidence of reliability and validity, the structural model was examined to evaluate the hypothesized relationships among the constructs in the research model (Hair et al. 2013). According to Henseler, Ringle, and Sarstedt (2012) and Hair et al.'s (2013) recommendations, the structural model proposed in the current study was evaluated with several measures,
The model explains $79 \%$ of variance for perceived website trust, $37 \%$ of variance for consumer attitude, $53 \%$ of variance for perceived risk, and $59 \%$ of variance for intentions to purchase travel online. To test hypotheses $1-13$, the structural equation model was tested in Figure 2. The global fit indicators were acceptable, APC $=0.182(\mathrm{P}<0.001)$, ARS $=0.784(\mathrm{P}<0.001)$, AARS $=0.719(\mathrm{P}<0.001)$, $\mathrm{AVIF}=2.629$, and GOF $=0.708$. The results show that all hypothesized relationships are supported except hypotheses 1,4 , and 11 .

Based on the results, the strongest predictors of perceived website trust were: perceived ease of use $(\beta=0.61, \mathrm{P}<$ 0.001 ), website quality $(\beta=0.48, \mathrm{P}<0.001)$, website reputation $(\beta=0.42, \mathrm{P}<0.001)$, and perceived usefulness $(\beta=$ $0.39, \mathrm{P}<0.001)$. Contrary to our predictions, consumer experience and proficiency $(\beta=0.08, \mathrm{P}<$ nonsignificant $)$ and website size $(\beta=0.08, \mathrm{P}<$ nonsignificant $)$ did not exhibit a significant predictive power in their relationship with the dependent variable (website trust); thus, the results support hypotheses $2,3,5,6$, and 7, while hypotheses 1 and 4 are rejected.

Findings also show that website trust is a significant and strong predictor of consumer attitude $(\beta=0.51, \mathrm{P}<0.001)$, perceived risk ( $\beta=-0.74, \mathrm{P}<0.001)$, and intentions to purchase $(\beta=0.04, \mathrm{P}<0.05)$. Finally, the influence of attitude on intention to purchase travel online $(\beta=0.69, \mathrm{P}<0.001)$ and perceived risk on intention to purchase $(\beta=-0.43, \mathrm{P}<$ $0.001)$ is found to be strong and highly significant, while perceived risk ( $\beta=0.06, \mathrm{P}<$ nonsignificant) has no influence on attitude; thus, hypotheses 9,10,12, and 13 are accepted, while hypothesis 11 is rejected.

To check for the mediating indirect effects of the variables on consumer intentions to purchase travel online through trust, perceived risk, and attitude, a separate analysis was performed based on Baron and Kenny's (1986) procedure. The results revealed that the influence of user experience, 
Table 4. Measurement Statistics of Construct Scales.

\begin{tabular}{|c|c|c|c|c|}
\hline Construct Indicators & $\begin{array}{l}\text { Indicator } \\
\text { Loadings }\end{array}$ & $\begin{array}{l}\text { Composite } \\
\text { Reliability }\end{array}$ & $\begin{array}{c}\text { Cronbach's } \\
\text { Alpha }\end{array}$ & $\begin{array}{l}\text { Average Variance } \\
\text { Extracted (AVE) }\end{array}$ \\
\hline $\begin{array}{l}\text { Intention to purchase } \\
\text { travel online }\end{array}$ & & 0.92 & 0.89 & 0.64 \\
\hline INTI & 0.94 & & & \\
\hline INT2 & 0.97 & & & \\
\hline INT3 & 0.92 & & & \\
\hline INT4 & 0.89 & & & \\
\hline Attitude & & 0.87 & 0.83 & 0.68 \\
\hline ATTI & 0.96 & & & \\
\hline ATT2 & 0.89 & & & \\
\hline ATT3 & 0.93 & & & \\
\hline Perceived risk & & 0.94 & 0.91 & 0.59 \\
\hline RSKI & 0.91 & & & \\
\hline RSK2 & 0.95 & & & \\
\hline RSK3 & 0.88 & & & \\
\hline Website trust & & 0.89 & 0.83 & 0.63 \\
\hline TRUI & 0.89 & & & \\
\hline TRU2 & 0.84 & & & \\
\hline TRU3 & 0.93 & & & \\
\hline TRU4 & 0.91 & & & \\
\hline Consumer experience & & 0.96 & 0.94 & 0.51 \\
\hline EXPI & 0.94 & & & \\
\hline EXP2 & 0.97 & & & \\
\hline EXP3 & 0.93 & & & \\
\hline Propensity to trust & & 0.91 & 0.85 & 0.64 \\
\hline PRTI & 0.90 & & & \\
\hline PRT2 & 0.94 & & & \\
\hline PRT3 & 0.87 & & & \\
\hline Reputation & & 0.93 & 0.91 & 0.67 \\
\hline REPI & 0.84 & & & \\
\hline REP2 & 0.87 & & & \\
\hline REP3 & 0.91 & & & \\
\hline Perceived size & & 0.97 & 0.94 & 0.73 \\
\hline SIZI & 0.94 & & & \\
\hline SIZ2 & 0.97 & & & \\
\hline SIZ3 & 0.89 & & & \\
\hline Perceived ease of use & & 0.93 & 0.91 & 0.62 \\
\hline PEUI & 0.93 & & & \\
\hline PEU2 & 0.91 & & & \\
\hline PEU3 & 0.96 & & & \\
\hline Perceived usefulness & & 0.87 & 0.83 & 0.58 \\
\hline PUSI & 0.94 & & & \\
\hline PUS2 & 0.92 & & & \\
\hline PUS3 & 0.97 & & & \\
\hline Website quality & & 0.89 & 0.82 & 0.67 \\
\hline Qull & 0.87 & & & \\
\hline Qul2 & 0.89 & & & \\
\hline Qul3 & 0.93 & & & \\
\hline Qul4 & 0.91 & & & \\
\hline
\end{tabular}

reputation, and website quality on intention to purchase travel online are completely mediated through trust, perceived risk and attitude, and the influences of propensity to trust, perceived ease of use, website size, and perceived usefulness are partially mediated. Attitude and perceived risk completely mediates the impact of website trust on consumer intention to purchase travel online.
Furthermore, the Cohen (1988) effect size $f^{2}$, defined as "the degree to which the phenomenon is present in the population," was used to further examine the substantive effect of the research model. Cohen (1988) suggested 0.02, 0.15, and 0.35 as operational definitions of small, medium, and large effect sizes, respectively. Thus, our model suggested that both website trust $\left(f^{2}=0.71\right)$ and intentions to purchase travel online 
Table 5. Discriminant Validity of the Constructs.

\begin{tabular}{|c|c|c|c|c|c|c|c|c|c|c|c|}
\hline \multirow[b]{2}{*}{ Construct } & \multicolumn{11}{|c|}{ Correlations and Square Roots of AVEs } \\
\hline & INT & ATT & RSK & TRU & EXP & PRT & REP & SIZ & PEU & PUS & QUL \\
\hline INT & $(0.8 \mid 8)$ & & & & & & & & & & \\
\hline ATT & 0.562 & $(0.871)$ & & & & & & & & & \\
\hline RSK & 0.410 & 0.792 & $(0.794)$ & & & & & & & & \\
\hline TRU & 0.392 & 0.621 & 0.721 & $(0.796)$ & & & & & & & \\
\hline EXP & 0.405 & 0.700 & 0.602 & 0.719 & $(0.874)$ & & & & & & \\
\hline PRT & 0.491 & 0.740 & 0.761 & 0.758 & 0.802 & $(0.791)$ & & & & & \\
\hline REP & 0.392 & 0.593 & 0.580 & 0.582 & 0.727 & 0.694 & $(0.893)$ & & & & \\
\hline SIZ & 0.529 & 0.568 & 0.647 & 0.497 & 0.604 & 0.506 & 0.648 & $(0.748)$ & & & \\
\hline PEU & 0.360 & 0.703 & 0.629 & 0.594 & 0.527 & 0.475 & 0.470 & 0.594 & $(0.709)$ & & \\
\hline PUS & 0.293 & 0.497 & 0.491 & 0.603 & 0.490 & 0.751 & 0.718 & 0.430 & 0.641 & $(0.837)$ & \\
\hline QUL & 0.419 & 0.620 & 0.473 & 0.594 & 0.603 & 0.619 & 0.493 & 0.643 & 0.590 & 0.783 & $(0.680)$ \\
\hline
\end{tabular}

Note: Bolded items are factor loadings. INT = Intentions to purchase; ATT = Attitude; RSK = Perceived risk; TRU = Trust; EXP = User experience; PRT = Propensity to trust; REP = Reputation; SIZ = Perceived size; PEU = Perceived ease of use; PUS = Perceived usefulness; QUL = Website quality .

$\left(f^{2}=0.58\right)$ have large effect sizes whereas perceived risk $\left(f^{2}=\right.$ $0.24)$ and attitude $\left(f^{2}=0.27\right)$ have medium effect sizes.

The study tests the predictive validity of the structural model following the Stone-Geisser $\mathrm{Q}^{2}$. According to Roldán and Sánchez-Franco (2012), in order to examine the predictive validity of the research model, the cross-validated construct redundancy $\mathrm{Q}^{2}$ is necessary. $\mathrm{A}^{2}$ greater than 0 implies that the model has predictive validity. In the main PLS model, $\mathrm{Q}^{2}$ is 0.69 for website trust, 0.51 for attitude, 0.46 for perceived risk and 0.62 for consumer intention to purchase travel online that is positive and hence satisfies this condition.

\section{Discussion and Conclusions}

\section{Discussion of Findings}

The aim of this study was to propose and empirically test a comprehensive model of antecedents and consequences of consumer's trust toward online travel websites. Seven factors are proposed for building consumer trust toward online travel websites: consumer experience, propensity to trust, reputation, perceived size, ease of use, perceived usefulness, and website quality. Perceived risk, attitude, and intention to purchase travel online act as consequences to website trust. Findings from Internet users $(\mathrm{N}=1,431)$ indicated that perceived ease of use, website quality, website reputation, and perceived usefulness are key indicators for building website trust. Trust is a key performance indicator for online travel organizations that influences perceived risk, attitude, and consumer intentions to purchase travel online.

Overall, the results provide support for the proposed model of consumer trust toward online travel websites. As expected, characteristics of both consumers (propensity to trust), online vendors (perceived reputation), and website (ease of use, perceived usefulness, and website quality) are found to be determinants of consumer trust toward online travel websites.
In terms of the antecedents of website trust, the SEM results show that propensity to trust has significant influence on website trust but consumer experience is not related to website trust; the findings highlight a positive relationship that is consistent with previous studies (e.g., Gefen 2000; Teo and Liu 2007; Beldad, de Jong, and Steehouder 2010). It was found that the level of consumer experience in terms of using online travel websites was not a significant predictor of trust toward online travel websites. This means that trust toward online travel websites will be almost the same between experienced and inexperienced consumers. However, on average, consumers with more experience with online travel websites will tend to trust online travel websites less than novice consumers.

The findings of this study revealed that perceived reputation is positively related to website trust but perceived website size is not related to website trust. One possible explanation for the lack of support for the relationship between perceived website size and website trust could be that the perceived size of website does not affect consumers' trust toward website as heavily as the perceived size of a physical store does. Online provider size is less easily perceived on the website than a physical store size. In the traditional business, consumers can easily assess an organization size themselves by its presence. But in the online environment, it is hard to assess the online vendor size through its website. Therefore, customers may not care much regarding the online vendor size. Furthermore, recognizing perceived reputation as a driver of website trust validates Yang et al. (2015) and Teo and Liu (2007) and Hsu et al. (2014) findings in online context.

The results also indicate that perceived ease of use and perceived usefulness are two relevant antecedents in order to form a website trust. Therefore, the TAM holds true for Egypt (i.e., a culture that is high in uncertainty avoidance, power distance, and masculinity and low in individualism). Prior studies have indicated concern regarding the applicability of the TAM in a culture that is high in uncertainty avoidance, power distance, and masculinity (McCoy, Galletta, and King 
Table 6. Loadings and Cross-Loadings of Measurement Items.

\begin{tabular}{|c|c|c|c|c|c|c|c|c|c|c|c|c|}
\hline ITEMS & INT & ATT & RSK & TRU & EXP & PRT & REP & SIZ & PEU & PUS & QUL & $P$ Value \\
\hline INTI & 0.892 & 0.314 & 0.286 & 0.252 & 0.109 & 0.347 & 0.188 & 0.399 & 0.167 & 0.042 & 0.208 & $<0.001$ \\
\hline INT2 & 0.973 & 0.121 & 0.225 & 0.353 & 0.131 & 0.134 & 0.519 & 0.211 & 0.261 & 0.391 & 0.142 & $<0.001$ \\
\hline INT3 & 0.860 & 0.233 & 0.033 & 0.103 & 0.231 & 0.314 & 0.304 & 0.262 & 0.514 & 0.221 & 0.528 & $<0.001$ \\
\hline INT4 & $0.88 I$ & 0.229 & 0.225 & $0.44 I$ & 0.347 & 0.351 & $0.51 \mathrm{I}$ & 0.038 & 0.387 & 0.251 & 0.199 & $<0.001$ \\
\hline ATTI & 0.209 & 0.836 & 0.229 & 0.422 & 0.259 & 0.246 & 0.146 & 0.211 & 0.223 & 0.617 & 0.315 & $<0.001$ \\
\hline ATT2 & 0.217 & 0.919 & 0.282 & 0.118 & 0.438 & 0.219 & 0.347 & 0.281 & 0.389 & 0.528 & 0.241 & $<0.001$ \\
\hline ATT3 & 0.104 & 0.874 & 0.415 & 0.336 & 0.236 & 0.338 & 0.411 & 0.389 & 0.418 & 0.515 & 0.321 & $<0.001$ \\
\hline RSKI & 0.211 & 0.201 & 0.934 & 0.245 & 0.319 & 0.393 & 0.548 & 0.148 & 0.558 & 0.305 & 0.646 & $<0.001$ \\
\hline RSK2 & -0.109 & 0.414 & 0.835 & 0.201 & 0.519 & 0.518 & 0.244 & 0.269 & 0.059 & 0.544 & 0.148 & $<0.001$ \\
\hline RSK3 & -0.223 & 0.014 & 0.843 & 0.392 & 0.447 & 0.542 & 0.487 & 0.118 & 0.422 & 0.221 & 0.315 & $<0.001$ \\
\hline TRUI & 0.092 & 0.192 & 0.136 & $0.95 I$ & 0.315 & 0.237 & 0.351 & 0.114 & 0.478 & 0.223 & 0.262 & $<0.001$ \\
\hline TRU2 & 0.028 & 0.104 & 0.038 & 0.844 & 0.231 & 0.321 & 0.418 & 0.317 & 0.353 & 0.452 & 0.193 & $<0.001$ \\
\hline TRU3 & -0.549 & 0.234 & 0.432 & 0.974 & 0.219 & 0.218 & 0.143 & 0.114 & 0.132 & 0.627 & 0.111 & $<0.001$ \\
\hline TRU4 & 0.338 & 0.149 & 0.331 & 0.812 & 0.128 & 0.224 & 0.143 & $0.24 I$ & 0.234 & 0.315 & $0.4 I I$ & $<0.001$ \\
\hline EXPI & 0.136 & 0.312 & 0.221 & 0.214 & 0.816 & 0.118 & 0.349 & 0.313 & 0.341 & 0.147 & 0.293 & $<0.001$ \\
\hline EXP2 & 0.383 & 0.331 & 0.421 & 0.639 & 0.835 & 0.456 & 0.292 & 0.553 & 0.171 & 0.338 & $0.45 I$ & $<0.001$ \\
\hline EXP3 & 0.294 & 0.341 & 0.234 & 0.321 & 0.816 & 0.254 & 0.118 & 0.214 & 0.451 & 0.493 & 0.607 & $<0.001$ \\
\hline PRTI & 0.224 & 0.384 & 0.485 & 0.352 & 0.321 & 0.912 & 0.519 & 0.244 & 0.317 & 0.324 & 0.251 & $<0.001$ \\
\hline PRT2 & 0.206 & -0.314 & 0.126 & 0.312 & 0.016 & 0.957 & 0.608 & 0.212 & 0.517 & 0.324 & 0.218 & $<0.001$ \\
\hline PRT3 & -0.311 & 0.121 & 0.215 & 0.353 & 0.419 & 0.934 & 0.359 & $0.45 I$ & 0.232 & 0.231 & 0.242 & $<0.001$ \\
\hline REPI & 0.204 & -0.123 & 0.233 & -0.153 & 0.221 & 0.214 & 0.874 & 0.362 & 0.434 & 0.431 & 0.528 & $<0.001$ \\
\hline REP2 & 0.221 & 0.239 & 0.215 & $0.24 I$ & 0.317 & 0.081 & $0.85 I$ & 0.048 & 0.437 & 0.231 & 0.249 & $<0.001$ \\
\hline REP3 & -0.029 & 0.226 & 0.229 & 0.412 & 0.219 & 0.254 & 0.816 & 0.511 & 0.323 & 0.457 & 0.315 & $<0.001$ \\
\hline SIZI & 0.217 & 0.139 & 0.432 & 0.338 & 0.108 & 0.349 & 0.147 & $0.86 I$ & 0.389 & 0.548 & 0.221 & $<0.001$ \\
\hline SIZ2 & 0.304 & 0.224 & 0.255 & 0.336 & 0.236 & 0.118 & 0.011 & 0.889 & 0.218 & 0.543 & 0.231 & $<0.001$ \\
\hline SIZ3 & 0.124 & 0.221 & -0.244 & 0.214 & 0.319 & 0.493 & 0.348 & 0.878 & 0.458 & 0.105 & 0.446 & $<0.001$ \\
\hline PEUI & -0.149 & -0.234 & 0.325 & -0.101 & 0.229 & 0.358 & 0.244 & 0.409 & 0.829 & 0.324 & 0.138 & $<0.001$ \\
\hline PEU2 & -0.243 & 0.024 & 0.143 & 0.442 & 0.267 & 0.446 & 0.217 & 0.078 & 0.922 & 0.221 & $0.47 \mid$ & $<0.001$ \\
\hline PEU3 & 0.092 & -0.232 & 0.546 & 0.331 & 0.125 & 0.237 & 0.291 & 0.284 & 0.878 & 0.228 & 0.025 & $<0.001$ \\
\hline PUSI & 0.038 & 0.224 & 0.248 & 0.304 & 0.201 & 0.521 & 0.148 & 0.127 & 0.153 & 0.852 & 0.523 & $<0.001$ \\
\hline PUS2 & 0.329 & -0.284 & 0.402 & 0.314 & 0.239 & 0.348 & 0.133 & 0.154 & 0.392 & 0.917 & 0.157 & $<0.001$ \\
\hline PUS3 & 0.318 & 0.129 & 0.341 & 0.123 & 0.148 & 0.234 & 0.273 & 0.431 & 0.294 & 0.915 & 0.421 & $<0.001$ \\
\hline QULI & 0.416 & 0.252 & -0.251 & 0.214 & 0.416 & 0.218 & 0.339 & 0.513 & 0.141 & 0.127 & 0.893 & $<0.001$ \\
\hline QUL2 & 0.183 & 0.321 & 0.361 & 0.139 & 0.135 & 0.246 & 0.232 & 0.443 & 0.501 & 0.328 & 0.821 & $<0.001$ \\
\hline QUL3 & 0.224 & 0.321 & 0.284 & 0.321 & 0.416 & 0.384 & 0.118 & 0.214 & 0.518 & 0.603 & 0.917 & $<0.001$ \\
\hline QUL4 & 0.234 & 0.183 & 0.405 & 0.272 & 0.621 & 0.112 & 0.339 & 0.254 & 0.137 & 0.174 & 0.819 & $<0.001$ \\
\hline
\end{tabular}

Note: INT = Intentions to purchase; ATT = Attitude; RSK = Perceived risk; TRU= Trust; EXP = User experience; PRT= Propensity to trust; REP = Reputation; SIZ = Perceived size; PEU= Perceived ease of use; PUS = Perceived usefulness; QUL = Website quality.

2007; Straub, Keil, and Brenner 1997). However, the current study results reveal useful insights regarding the applicability and generalizability of TAM in a culture that is high in uncertainty avoidance, power distance, and masculinity. The results of this study are consistent with Adams, Nelson, and Todd (1992), which pointed out that PEU plays a critical role in the early adaption stages. Perceived website quality emerged as a strong predictor of website trust. Therefore, the higher the perceived quality of online travel website, the more users will trust in online travel website. Therefore, the current study shows that website quality is an important predictor of trust toward online travel websites, which is consistent with previous studies (e.g., Filieri 2015; Kim, Chung, and Lee 2011; Wang et al. 2015).
Results regarding consequences of website trust are consistent with the findings of Teo and Liu (2007), Jarvenpaa, Tractinsky, and Vitale (2000), and Amaro and Duarte (2015). The findings of this study acknowledge that trustworthy relations between the consumer and online travel provider have a significant and positive effect on customer attitude toward online travel websites and between consumers' attitude and their intention to purchase travel online. Consumers' attitude toward online travel websites is the most relevant determinant of intentions to purchase travel online. The results of this study are consistent with Amaro and Duarte (2015), which pointed out that consumers' attitude is the most relevant determinant of consumers' intentions to purchase travel online. Finally, website trust reduces consumers' perceived 


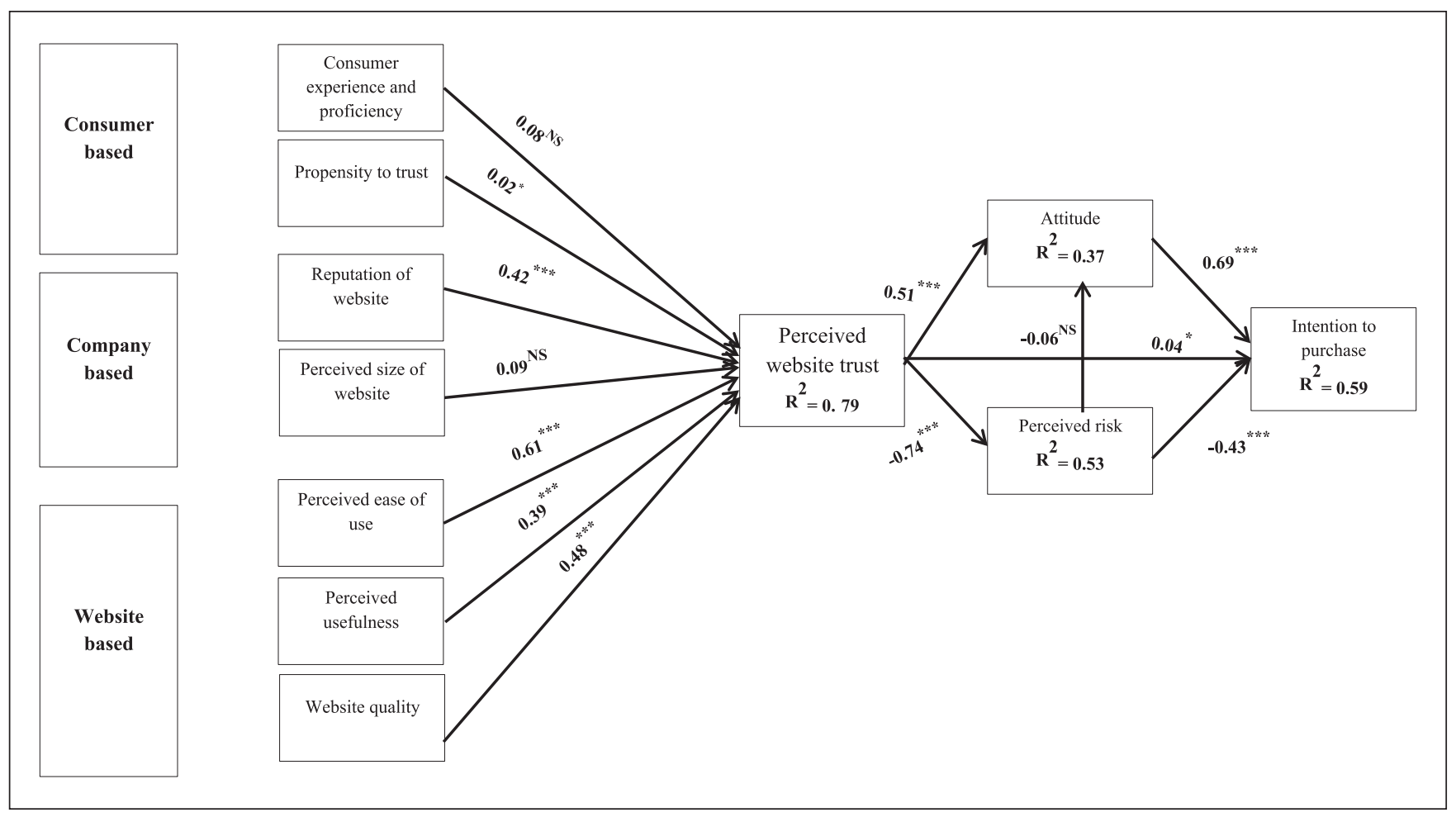

Figure 2. Partial least squares analysis results.

Note: The asterisks represent the level of significance of the coefficient. $* 0.05 ; * * 0.01 ; * * * 0.001$.

risk associated with purchasing travel online. Although perceived risk has no influence on consumer attitude toward online travel websites, since it has a negative influence on consumer intentions to purchase travel online, it may discourage consumers from purchasing. The TRA is confirmed by the results of the current study, which revealed that customers' trust toward online travel websites is significantly positively related to their attitude toward the online travel websites, and consumers' attitude is positively related with customers' intentions to purchase travel online. This result is consistent with prior empirical studies (e.g., Teo and Liu 2007; Amaro and Duarte 2015; Jarvenpaa, Tractinsky, and Vitale 2000).

\section{Managerial Implications}

Trust has become a top concern for online travel websites as evidenced by prior studies (Kim, Chung, and Lee 2011; Ayeh, $\mathrm{Au}$, and Law 2013a). This study was couched on the premise that prior studies have largely ignored the factors leading to consumers' trust toward online travel websites as well as the consequences of consumers' trust toward online travel websites, especially in a developing country. As such, a strong empirical inquiry on analyzing the antecedents and consequences of customers' trust toward online travel websites as identified by the literature was needed. The present study's findings have revealed some important implications for online travel providers and academic researchers as well as making a significant contribution to the body of knowledge in a number of different ways.

The results of this research have relevant practical implications for marketing practitioners and managers who design strategic plans and implement tools to improve the performance of online travel shopping websites.

First, knowledge of the antecedents and consequences of consumer trust and the influence of these factors on intentions to purchase travel online are useful for managers who should develop strategies and actions aimed at increasing the consumer trust in their websites and, consequently, the consumers' intentions to purchase travel online. The current study has provided empirical validation of a model that can help online travel providers to understand the antecedents and consequences of trust toward online travel websites. Perceived ease of use and perceived usefulness emerged as crucial success factors for building trust toward online travel websites and consequently, attitude and intentions to purchase travel online; therefore, actions can be taken by managers to increase perceived ease of use and perceived usefulness. Online travel providers can utilize the advances of technology to facilitate convenience in selling travel online. For instance, online travel providers can provide apps for mobile devices to purchase travel.

Second, our study findings have important implications for international marketers who want to target the Egyptian market. Our study reveals that PEU plays a critical role in influencing consumer trust toward online travel websites. In other words, Egyptian consumers are likely to be more worried about their 
ability to use the website than the online travel shopping benefits when making decisions about e-commerce adaption.

Third, another recommendation for online travel providers to keep high levels of trust would be to improve technical features such as service quality, information quality, and service quality. For instance, online travel providers can provide consumers with information systems with safe payment mechanism, privacy protection mechanism, and high transmission quality. Furthermore, online travel providers should encourage consumers to enter their personal information to utilize customized and personalized services. In addition, online travel providers can increase their websites' reputation through publicity and advertising.

Finally, this study revealed that consumers' attitude toward online travel websites is the most relevant determinant of consumers' intention to purchase online. Thus, online travel providers need to pay attention to the aspects that build a favorable attitude. The current study evidenced some of those aspects, for example, trust. Perceived risk influences consumer intentions to purchase online, and actions can be taken by online travel providers to reduce the perceived risk through, for instance, a strong website reputation, providing fulfilling transactions, providing consumers with information about consumer rights and money-back guarantees, and using security approval symbols.

\section{Theoretical Implications}

The findings of this study contribute to the literature by expanding the extant literature on online trust by assessing the drivers and outcomes of trust toward online travel websites in an emerging Middle East context. These results are important because they empirically test theories predominantly developed in developed countries, in the context of a vigorous emerging Middle East marketplace, which increasingly attracts international marketers who want to target the Egyptian market. Therefore, the theoretical implications of this study are that consumer trust toward online travel websites depends on three main drivers: (1) those related to consumers' experience and proficiency and propensity to trust; (2) those related to the reputation of the website and the perceived size of the website; and (3) those related to the perceived ease of use, perceived usefulness, and website quality. Furthermore, previous studies have often not adequately distinguished between consumer trust, attitude, and perceived risk and concomitantly have not understood their relationships with each other or how they influence purchase intentions. Therefore, distinguishing between these concepts both empirically and conceptually will provide important insights into their distinct roles in the online context.

\section{Limitations and Future Research Directions}

Like any other study, ours is bound by certain limitations that also provide fertile grounds for further research. First, this study employed a convenience sample. Although being a strong sample in terms of diversity and size, generalizations of the results must be made with caution. Therefore, future studies can use random sampling of general consumers. Second, this study did not consider cross-cultural issues; any comparative study of developed and developing countries would make a worthwhile contribution to the body of knowledge. Third, another limitation of the current study is related to online travel purchase definition. In this study, online travel purchase definition is a little broad; therefore, the results maybe not suitable to all online travel product categories. Therefore, future studies should examine the validity of the proposed model on a specific travel product or service. Fourth, the variables of this study have been measures at a single point of time. Thus, future studies should use longitudinal analysis in order to validate the proposed model. Finally, although the antecedents of consumer trust toward online travel websites explained a substantial amount of its variance, there are some other important dimensions that have not been included in the research model, representing opportunities for further research (e.g., consumers' satisfaction with previous experience and perceived source credibility).

\section{Appendix}

Table 7. Descriptive Statistics and Normality Tests of the Constructs in the Model.

\begin{tabular}{|c|c|c|c|c|c|c|}
\hline Statistics & Mean & SD & $\begin{array}{l}\text { Corrected } \\
\text { Correlation } \\
\text { Item-Total }\end{array}$ & Skewness & Kurtosis & Supporting Literature \\
\hline \multicolumn{7}{|l|}{ Intentions to purchase travel online (INT) } \\
\hline $\begin{array}{l}\text { My willingness to purchase a travel product from this website is high } \\
\text { (INTI). }\end{array}$ & 3.8 & 0.837 & 0.670 & -0.758 & 0.630 & \multirow{4}{*}{$\begin{array}{l}\text { Kim, Xu, and Gupta (20I2); Mukherjee } \\
\text { and Nath (2007); Bigne et al. (20I0); } \\
\text { Castaneda, Munoz-Leiva, and Luque } \\
(2007)\end{array}$} \\
\hline $\begin{array}{l}\text { If I were to purchase a travel product, I would consider purchasing it } \\
\text { from this website (INT2). }\end{array}$ & 4.5 & 0.785 & 0.782 & -0.654 & 0.083 & \\
\hline I intend to continue visiting the website in the future (INT3). & 4.6 & 0.762 & 0.689 & -0.493 & 0.704 & \\
\hline $\begin{array}{l}\text { My intention is to continue using this website rather than an alternative } \\
\text { one (INT4). }\end{array}$ & 3.9 & 0.830 & 0.703 & -0.670 & 0.409 & \\
\hline
\end{tabular}


Table 7. (continued)

\begin{tabular}{|c|c|c|c|c|c|c|}
\hline Statistics & Mean & SD & $\begin{array}{l}\text { Corrected } \\
\text { Correlation } \\
\text { Item-Total }\end{array}$ & Skewness & Kurtosis & Supporting Literature \\
\hline \multicolumn{7}{|l|}{ Attitude (ATT) } \\
\hline I like the idea of purchasing travel online from this website (ATTI). & 3.6 & 0.840 & 0.758 & -0.583 & 0.710 & \multirow{3}{*}{$\begin{array}{l}\text { Chen and Wells (1999); } \\
\text { Castaneda, Munoz-Leiva, and Luque } \\
(2007)\end{array}$} \\
\hline Purchasing travel online from this website is a wise idea (ATT2). & 4.2 & 0.687 & 0.683 & -0.472 & 0.653 & \\
\hline Purchasing travel online from this website would be pleasant (ATT3). & 4.7 & 0.745 & 0.704 & -0.609 & 0.736 & \\
\hline \multicolumn{7}{|l|}{ Perceived risk (RSK) } \\
\hline $\begin{array}{l}\text { I believe that the risk of purchasing online from this online travel } \\
\text { website is very high (RSKI). }\end{array}$ & 4.5 & 0.829 & 0.765 & -0.583 & 0.359 & \multirow[t]{3}{*}{$\begin{array}{l}\text { Amaro and Duarte (20I5); } \\
\text { Shim et al. (200I) }\end{array}$} \\
\hline $\begin{array}{l}\text { There is too much uncertainty associated with purchasing online from } \\
\text { this online travel website (RSK2). }\end{array}$ & 3.6 & 0.914 & 0.803 & -0.691 & -0.263 & \\
\hline $\begin{array}{l}\text { Compared with other methods of purchasing, shopping online is riskier } \\
\text { (RSK3). }\end{array}$ & 4.1 & 0.780 & 0.794 & -0.480 & -0.594 & \\
\hline \multicolumn{7}{|l|}{ Trust (TRU) } \\
\hline I believe online travel products sites are trustworthy (TRUI). & 4.6 & 0.774 & 0.784 & -0.513 & 0.487 & \multirow{4}{*}{$\begin{array}{l}\text { (Morgan and Hunt I994; } \\
\text { Kim, Chung, and Lee 20I I; } \\
\text { Corbitt, Thanasankit, and Yi 2003; } \\
\text { Filieri 20I5; Kim, Ferrin, and Rao 2008) }\end{array}$} \\
\hline This online travel products sites are reliable (TRU2). & 3.7 & 0.809 & 0.832 & -0.620 & 0.833 & \\
\hline This online travel product website has integrity (TRU3) & 4.6 & 0.769 & 0.790 & -0.793 & 0.572 & \\
\hline $\begin{array}{l}\text { I believe most e-commerce travel web sites will perform to the } \\
\text { customers' utmost benefit (TRU4). }\end{array}$ & 4.3 & 0.752 & 0.708 & -0.394 & 0.427 & \\
\hline \multicolumn{7}{|l|}{ Experience (EXP) } \\
\hline $\begin{array}{l}\text { Prior to your participation in this study, how would you rate your level } \\
\text { of experience in terms of using this website? (EXPI). }\end{array}$ & 4.2 & 0.803 & 0.847 & -0.596 & 0.604 & \multirow[t]{3}{*}{$\begin{array}{l}\text { Smith, Menon, and Sivakumar (2005); } \\
\text { Filieri (2015) }\end{array}$} \\
\hline $\begin{array}{l}\text { How would you characterize your knowledge about the Internet in } \\
\text { general? (EXP2). }\end{array}$ & 3.8 & 0.843 & 0.794 & -0.810 & 0.474 & \\
\hline Number of years of Internet experience (EXP3) & 4.6 & 0.819 & 0.840 & -0.603 & 0.594 & \\
\hline \multicolumn{7}{|l|}{ Propensity to trust (PRT) } \\
\hline It is easy for me to trust people and most things in my life (PRTI). & 4.3 & 0.765 & 0.769 & -0.490 & 0.174 & \multirow{3}{*}{$\begin{array}{l}\text { (Teo and Liu 2007; Cheung and Lee } \\
\text { 200I; Bianchi and Andrews 20I2) }\end{array}$} \\
\hline My tendency to trust people or things in my life is high (PRT2). & 4.5 & 0.739 & 0.815 & -0.671 & 0.403 & \\
\hline $\begin{array}{l}\text { I tend to trust people and things in my life even when I have little } \\
\text { knowledge about them (PRT3). }\end{array}$ & 4.6 & 0.705 & 0.840 & -0.583 & 0.692 & \\
\hline \multicolumn{7}{|l|}{ Reputation (REP) } \\
\hline This online travel website is well known (REPI). & 4.2 & 0.740 & 0.874 & -0.389 & 0.283 & \multirow{3}{*}{$\begin{array}{l}\text { Teo and Liu (2007); Doney and Cannon } \\
\text { (1997); Jarvenpaa, Tractinsky, and } \\
\text { Vitale (2000) }\end{array}$} \\
\hline This online travel website has a good reputation in the market (REP2). & 3.9 & 0.784 & 0.893 & -0.440 & 0.190 & \\
\hline This online travel website has a reputation for being honest (REP3). & 4.4 & 0.840 & 0.739 & -0.507 & 0.305 & \\
\hline \multicolumn{7}{|l|}{ Perceived size (SIZ) } \\
\hline This online travel website is a very large company (SIZI) & 3.7 & 0.852 & 0.917 & -0.705 & 0.417 & \multirow{3}{*}{$\begin{array}{l}\text { Teo and Liu (2007); Doney and Cannon } \\
\text { (1997); Jarvenpaa, Tractinsky, and } \\
\text { Vitale (2000) }\end{array}$} \\
\hline $\begin{array}{l}\text { This online travel website is one of the industry's biggest suppliers on } \\
\text { the Web (SIZ2). }\end{array}$ & 4.5 & 0.693 & 0.794 & -0.474 & 0.253 & \\
\hline This online travel website has global presence (SIZ3). & 4.7 & 0.843 & 0.739 & -0.590 & 0.309 & \\
\hline \multicolumn{7}{|l|}{ Perceived ease of use (PEU) } \\
\hline I think that learning to use online travel website would be easy (PEUI). & 4.3 & 0.693 & 0.648 & -0.849 & 0.837 & \multirow{3}{*}{$\begin{array}{l}\text { Davis (1989); Cheng, Lam, and Yeung } \\
\text { (2006); Moore and Benbasat (199I); } \\
\text { Castaneda, Munoz-Leiva, and Luque } \\
\text { (2007) }\end{array}$} \\
\hline $\begin{array}{l}\text { I think that interaction with online travel websites does not require a } \\
\text { lot of mental effort (PEU2. }\end{array}$ & 3.8 & 0.840 & 0.603 & -0.504 & 0.680 & \\
\hline $\begin{array}{l}\text { I think that it is easy to use online travel website to accomplish my } \\
\text { travel tasks (PEU3). }\end{array}$ & 4.2 & 0.594 & 0.780 & -0.349 & 0.743 & \\
\hline \multicolumn{7}{|l|}{ Perceived usefulness (PUS) } \\
\hline $\begin{array}{l}\text { Purchasing travel online from this website helps me to clear doubts } \\
\text { when I plan a travel (PUSI). }\end{array}$ & 3.9 & 0.853 & 0.740 & -0.607 & 0.684 & \multirow{3}{*}{$\begin{array}{l}\text { Davis (1989); Cheng, Lam, and Yeung } \\
\text { (2006); Moore and Benbasat (I99I); } \\
\text { Castaneda, Munoz-Leiva, and Luque } \\
\text { (2007) }\end{array}$} \\
\hline $\begin{array}{l}\text { Purchasing travel online from this website helps me to organize travels } \\
\text { in a more efficient way (PUS2). }\end{array}$ & 3.5 & 0.729 & 0.683 & -0.529 & 0.403 & \\
\hline $\begin{array}{l}\text { In general, purchasing travel online from this website is useful to plan } \\
\text { travels (PUS3). }\end{array}$ & 4.2 & 0.570 & 0.659 & -0.642 & 0.379 & \\
\hline \multicolumn{7}{|l|}{ Website quality (QUL) } \\
\hline This travel website provides sufficient information (QULI). & 4.4 & 0.570 & 0.693 & -0.529 & 0.572 & \multirow{4}{*}{$\begin{array}{l}\text { (Filieri 20I5; Hsu et al. 20I4; } \\
\text { Teo, Srivastava, and Jiang 2009) }\end{array}$} \\
\hline This travel website provides reliable information (QUL2). & 4.3 & 0.671 & 0.730 & -0.704 & 0.685 & \\
\hline This travel website provides dependable services (QUL3). & 4.2 & 0.694 & 0.682 & -0.396 & 0.504 & \\
\hline This travel website guarantees users' privacy and security (QUL4). & 3.7 & 0.703 & 0.831 & -0.753 & 0.483 & \\
\hline
\end{tabular}

\section{Declaration of Conflicting Interests}

The author(s) declared no potential conflicts of interest with respect to the research, authorship, and/or publication of this article.

\section{Funding}

The author(s) received no financial support for the research, authorship, and/or publication of this article. 


\section{References}

Aaker, David A., V. Kumar, and George S. Day. 2007. Marketing Research, 7th ed. Milton, Queensland: John Wiley \& Sons Australia.

Adams, D., R. R. Nelson, and P. A. Todd. 1992. "Perceived Usefulness, Ease of Use, and Usage of Information Technology: A Replication." MIS Quarterly 16 (2): 227-47.

Agag, G., and A. El-Masry. 2016a. "Understanding Consumer Intention to Participate in Online Travel Community and Effects on Consumer Intention to Purchase Travel Online and WOM: An Integration of Innovation Diffusion Theory and TAM with trust." Computers in Human Behaviour. Published online February 18. doi:10.1016/j.chb.2016.02.038.

Agag, G., and A. El-Masry. 2016b. "Understanding the Determinants of Hotel Booking Intentions Andmoderating Role of Habit." International Journal of Hospitality Management 54:52-67.

Aiken, K. D., and D. M. Boush. 2006. "Trustmarks, ObjectiveSource Ratings, and Implied Investments in Advertising: Investigating Online Trust and the Context Specific Nature of Internet Signals." Journal of the Academy of Marketing Science 34 (3): 308-23.

Ajzen, I. 2011. "Behavioral Interventions: Design and Evaluation Guided by the Theory of Planned Behavior." In Social psychology for program and policy evaluation, edited by M. M. Mark, S. I. Donaldson, and B. C. Campbell, 74-100. New York: Guilford.

Ajzen, I., and M. Fishbein. 1980. Understanding Attitudes and Predicting Social Behavior. Englewood Cliffs, NJ: Prentice Hall.

Aladwani, A. 2003. "Key Internet Characteristics and E-commerce Issues in Arab World." Information Technology and People 27 (1): 9-20.

Aldhmour, F., and R. Shannak. 2009. "The Effective Utilization of Information and Communication Technology and Its Impact on Competitive Advantage." European Journal of Scientific Research 29 (3): 302-14.

Alsajjan, B., and C. Dennis. 2010. "Internet Banking Acceptance Model: Cross-Market Examination." Journal of Business Research 63 (9): 957-63.

Amaro, S., and P. Duarte. 2013. "Online Travel Purchasing: A Literature Review." Journal of Travel \& Tourism Marketing 30 (8): 755-85.

Amaro, S., and P. Duarte. 2015. "An Integrative Model of Consumers' Intentions to Purchase Travel Oline." Tourism Management 46:64-79.

Armstrong, J. S., and T. S. Overton. 1977. "Estimating Nonresponse Bias in Mail Surveys." Journal of Marketing Research 14:396-402.

Ashraf, A. R., N. T. Thongpapanl, and S. Auh. 2014. "The Application of the Technology Acceptance Model under Different Cultural Contexts: The Case of Online Shopping Adoption." Journal of International Marketing 22 (3): 68-93.

Ayeh, J. K. 2015. “Travellers' Acceptance of Consumer-Generated Media: An Integrated Model of Technology Acceptance and Source Credibility Theories." Computers in Human Behavior 48:173-80.

Ayeh, J. K., N. Au, and R. Law. 2013a. "'Do We Believe in TripAdvisor?' Examining Credibility Perceptions and Online
Travellers' Attitude toward Using User-generated Content." Journal of Travel Research 52 (4): 437-52.

Ayeh, J. K., N. Au, and R. Law. 2013b. "Predicting the Intention to Use Consumer Generated Media for Travel Planning." Tourism Management 35:132-43.

Bagozzi, R., and Y. Yi. 1988. "On the Evaluation of Structural Equation Models." Journal of the Academy of Marketing Science 16 (1): 74-94.

Barclay, D., C. Higgins, and R. Thompson. 1995. "The Partial Least Squares (PLS) Approach to Causal Modeling: Personal Computer Adoption and Use as an Illustration." Technology Studies 2 (2): 285-309.

Baron, R. M., and D. A. Kenny. 1986. "The Moderator-Mediator Variable Distinctionin Social Psychological Research: Conceptual, Strategic, and Statistical Consider-ations." Journal of Personality and Social Psychology 51:1173-82.

Bartlett, J., J. Kotrlik, and C. Higgins. 2010. "Organizational Research: Determining Appropriate Sample Size in Survey Research." Information Technology, Learning, and Performance Journal 19 (1): 43-50.

Beirmann, D. 2003. Restoring Tourism Destination in Crisis: A Strategic marketing Approach. St. Leonards, New Zealand: Allen \& Unwin.

Beldad, A., M. de Jong, and M. Steehouder. 2010. "How Shall I Trust the Faceless and the Intangible? A Literature Review on the Antecedents of Online Trust." Computers in Human Behavior 26 (5): 857-68.

Bhuasiri, W., O. Xaymoungkhoun, H. Zo, and J. Rho. 2012. "Critical Success Factors for E-learning in Developing Countries: A Comparative Analysis between ICT Experts and Faculty." Computers and Education 58 (2): 843-55.

Bianchi, C., and L. Andrews. 2012. "Risk, Trust, and Consumer Online Purchasing Behaviour: A Chilean Perspective." International Marketing Review 29 (3): 253-75.

Bigne, E., S. Sanz, C. Ruiz, and J. Aldas. 2010. "Why Some Internet Users Don't Buy Air." In Information and Communication Technologies in Tourism 2010: Proceedings of the International Conference in Lugano, Switzerland, February 10-12, 2010 , edited by U. Gretzel, R. Law, and M. Fuchs, 209-21. New York, NY: Springer.

Brakus, J. J., B. H. Schmitt, and L. Zarantonello. 2009. "Brand Experience: What Is It? How Is It Measured? Does It Affect Loyalty?" Journal of Marketing 73 (3): 52-68.

Buhalis, D., and R. Law. 2008. "Progress in Information Technology and Tourism Management: 20 Years on and 10 Years after the Internet: The State of eTourism Research.” Tourism Management 29 (4): 609-23.

Casaló, L. V., C. Flavian, and M. Guinaliu. 2007. "The Influence of Satisfaction, Perceived Reputation and Trust on a Consumer's Commitment to a Website." Journal of Marketing Communications 13 (1): 1-17.

Casaló, L., C. Flavián, and M. Guinalíu. 2008. "The Role of Perceived Usability, Reputation, Satisfaction and Consumer Familiarity on the Website Loyalty Formation Process." Computers in Human Behaviour 24 (2): 325-45.

Casaló, L. V., C. Flavián, and M. Guinaliu. 2010. "Determinants of the Intention to Participate in Firm-Hosted Online Travel Communities and Effects on Consumer Behavioral Intentions." Tourism Management 31:898-911. 
Castaneda, J. A., F. Munoz-Leiva, and T. Luque. 2007. "Web Acceptance Model (WAM): Moderating Effects of User Experience." Information \& Management 44:384-96.

Chang, H. C., and S. W. Chen. 2008. "The Impact of Online Store Environment Cues on Purchase Intention: Trust and Perceived Risk as a Mediator." Online Inf. Rev 32 (6): 818-41.

Chen, C. 2006. "Identifying Significant Factors Influencing Consumer Trust in an Online Travel Site." Information Technology and Tourism 8:197-214.

Chen, Q., and W. D. Wells. 1999. "Attitude toward the Site." Journal of Advertising Research 39 (5): 27-37.

Chen, Y., X. Yan, W. Fan, and M. Gordon. 2015. "The Joint Moderating Role of Trust Propensity and Gender on Consumers' Online Shopping Behavior." Computers in Human Behavior 43:272-83.

Chen, Y. H., and S. Barnes. 2007. "Initial Trust and Online Buyer Behaviour." Industrial Management and Data Systems 107 (1): 21-36.

Cheng, H. H., and S. W. Huang. 2013. "Exploring Antecedents and Consequence of Online Group-Buying Intention: An Extended Perspective on Theory of Planned Behavior." International Journal of Information Management 33:185-98.

Cheng, T. C., D. Y. Lam, and A. C. Yeung. 2006. "Adoption of Internet Banking: An Empirical Study in Hong Kong." Decision Support System 42 (3): 1558-72.

Cheung, C. M., and M. K. Lee. 2001. "Trust in Internet Shopping: Instrument Development and Validation through Classical and Modern Approaches." Journal of Global Information Management 9:23-35.

Chin, W. W. 2010. "How to Write Up and Report PLS Analyses." In Handbook of Partial Least Squares: Concepts, Methods and Applications in Marketing and Related Fields, edited by V. E. Vinzi, W. W. Chin, J. Henseler, and H. Wang, 655-690. Berlin: Springer.

Chiou, W. C., C. C. Lin, and C. Perng. 2010. “A Strategic Framework for Website Evaluation Based on a Review of the Literature from 1995-2006." Information \& Management 47 (5): 282-90.

Chiu, C. M., H. Y. Huang, and Y. C. Hui. 2010. "Antecedents of Trust in Online Auctions." Electronic Commerce Research and Applications 9 (2): 148-59.

Chow, S., and R. Holden. 1997. "Toward an Understanding of Loyalty: The Moderating Role of Trust." Journal of Managerial Issues 9 (3): 275-98.

Cohen, J. 1988. Statistical Power Analysis for the Behavioral Sciences. New York: Academic Press.

Corbitt, B. J., T. Thanasankit, and H. Yi. 2003. "Trust and E-commerce: A Study of Consumer Perceptions." Electronic Commerce Research and Applications 2 (3): 203-15.

Davis, F. D. 1986. "A Technology Acceptance Model for Empirically Testing New End-User Information Systems: Theory and Results." PhD diss., Sloan School of Management Massachusetts Institute of Technology, Amherst, MA.

Davis, F. D. 1989. "Perceived Usefulness, Perceived Ease of Use and User Acceptance of Information Technology." MIS Quarterly 13 (3): 319-40.

De Leeuw, E. D. 2008. "Choosing the Method of Data Collection." In International Handbook of Survey Methodology, edited by E. D. de Leeuw, J. J. Hox, and D. A. Dillman, 113-35. New York: Lawrence Erlbaum.
De Ruyter, K., M. Wetzels, and M. Kleijnen. 2001. "Customer Adoption of E-service: An Experimental Study." International Journal of Service Industry Management 12 (2): 184-207.

DeLone, W. H., and E. R. McLean. 2003. "The DeLone and McLean Model of Information Systems Success: A Ten-Year Update." Journal of Management Information Systems 19 (4): 9-30.

Doney, P. M., and J. P. Cannon. 1997. "An Examination of the Nature of Trust in Buyer-Seller Relationships." Journal of Marketing 61 (2): 35-51.

Eid, R., and H. El-Gohary. 2015. "Muslim Tourist Perceived Value in the Hospitality and Tourism Industry." Journal of Travel Research 54 (6): 774-87.

Egyptian Ministry of Tourism. 2014. "Egyptian Tourism Statistics." Egyptian Ministry of Tourism. http:/www.tourism.gov.eg/ Pages/TourismIndicators.aspx (accessed February 10, 2016).

Elbeltagi, I., and G. Agag. 2016. "E-retailing Ethics and Its Impact on Customersatisfaction and Repurchase Intention: A Cultural and Commitment-Trust Theory Perspective." Internet Research 26 (1): 288-310.

El-Ansary, O., and A. Roushdy. 2013. "Factors Affecting Egyptian Consumers' Intentions for Accepting Online Shopping." Journal of American Academy of Business, Cambridge 19 (1): 191-201.

El-Gohary, H. 2012. "Factors Affecting E-marketing Adoption and Implementation in Tourism Firms: An Empirical Investigation of Egyptian Small tourism Organisations Hatem." Tourism Management 33:1256-69.

Escobar-Rodríguez, T., and E. Carvajal-Trujillo. 2014. “Online Purchasing Tickets for Low Cost Carriers an Application of the Unified Theory of Acceptance and Use of Technology (UTAUT) Model." Tourism Management 43 (August): 70-88.

Falcone, R., M. P. Singh, and Y. H. Tan. 2001. Trust in Cybersocieties: Integrating the Human and Artificial Perspectives. New York: Springer.

Filieri, R. 2015. "Why Do Travelers Trust TripAdvisor? Antecedents of Trust towards Consumer-Generated Media and Its Influence on Recommendation Adoption and Word of Mouth." Tourism Management 51:174-85.

Fishbein, M., and I. Ajzen. 1975. Belief, Attitude, Intention and Behaviour: An Introduction to Theory and Research. Reading, MA: Addison-Wesley.

Flavian, C., M. Guinalíu, and R. Gurrea. 2006. "The Role Played by Perceived Usability, Satisfaction and Consumer Trust on Website Loyalty." Information \& Management 43 (1): 1-14.

Fornell, C., and D. F. Larcker. 1981. "Evaluating Structural Equation Models with Unobservable Variables and Measurement Error." Journal of Marketing Research 18:39-50.

Fox, S., and M. Madden, 2005. "Pew internet and American life project." Retrived from http://www.pewinternet.org/files/oldmedia/Files/Reports/2006/PIP_Generations_Memo.pdf.pdf

Gardiner, S., C. King, and D. Grace. 2012. "Travel Decision Making: An Empirical Examination of Generational Values, Attitudes, and Intentions Sarah." Journal of Travel Research 52 (3): 310-24.

Gefen, D. 2000. "E-commerce: The Roles of Familiarity and Trust." Omega 28:725-37.

Gefen, D., E. Karahanna, and D. W. Straub. 2003. "Trust and TAM in Online Shopping: An Integrated Model.” MIS Quarterly 27 (1): 51-90. 
Gefen, D., and D. W. Straub. 2003. "Managing User Trust in B2C E-services." E-Service Journal 2 (2): 7-24.

Graziano, W. G., and R. M. Tobin. 2002. "Agreeableness: Dimension of Personality or Social Desirability Artifact?" Journal of Personality 70 (5): 695-728.

Gregori, N., R. Daniele, and L. Altinay. 2014. “Affiliate Marketing in Tourism: Determinants of Consumer Trust." Journal of Travel Research 53 (2): 196-210.

Griffin, A., and J. R. Hauser. 1993. "The Voice of the Customer." Marketing Science 12 (1): 1-27.

Hair, J. F., W. C. Black, H. J. Babin, and R. E. Anderson. 2010. Multivariate Data Analysis, 7th ed. Upper Saddle River, NJ: Prentice Hall.

Hair, J. F., C. M. Ringle, G. T. Hult, and M. Sarstedt. 2013. A Primer on Partial Least Squares Structural Equation Modeling (PLS-SEM). Thousand Oaks, CA: Sage.

Hair, J. F., C. M. Ringle, and M. Sarstedt. 2011. "PLS-SEM: Indeed a Silver Bullet." Journal of Marketing Theory and Practice 19 (2): 139-51.

Ham, S., W. G. Kim, and H. W. Forsythe. 2008. "Restaurant Employees' Technology Use Intention: Validating Technology Acceptance Model with External Factors." Journal of Hospitality \& Leisure Marketing 17 (1/2): 78-98.

Han, T. H., B. Nguyenb, and T. J. Lee. 2015. "Consumer-based Chain Restaurant Brand Equity, Brand Reputation, and Brand Trust." International Journal of Hospitality Management 50:84-93.

Henseler, J., C. M. Ringle, and M. Sarstedt. 2012. "Using Partial Least Squares Path Modeling in International Advertising Research: Basic Concepts and Recent Issues." In Handbook of Research in International Advertising, edited by S. Okazaki, 252-76. Cheltenham, UK: Edward Elgar.

Henseler, J., C. M. Ringle, and R. R. Sinkovics. 2009. "The Use of Partial Least Squares Path Modeling in International Marketing." Advances in International Marketing 20:277-319.

Herbig, P., J. Milewicz, and J. Golden. 1994. "A Model of Reputation Building and Destruction." Journal of Business Research 31:23-31.

Heung, V. C. S. 2003. "Internet Usage by International Travellers: Reasons and Barriers." International Journal of Contemporary Hospitality Management 15 (7): 370-78.

Ho, C., and Y. L. Lee. 2007. "The Development of an E-travel Service Quality Scale.” Tourism Management 28 (6): 1434-49.

Ho, L. A., T. H. Kuo, and B. Lin. 2010. "Influence of Online Learning Skills in Cyberspace." Internet Research 20 (1): $55-71$.

Hsu, M. H., C. M. Chang, K. K. Chu, and Y. J. Lee. 2014. "Determinants of Repurchase Intention in Online GroupBuying: The Perspectives of DeLone \& McLean IS Success Model and Trust." Computers in Human Behavior 36:234-45.

Hsu, Meng-Hsiang, Chuang Li-Wen, and Hsu Cheng-Se. 2014. "Understanding Online Shopping Intention: The Roles of Four Types of Trust and Their Antecedents." Internet Research 24 (3): 332-52.

Hsu, M. H., C. M. Chang, and L. W. Chuang. 2015. "Understanding the Determinants of Online Repeat Purchase Intentionand Moderating Role of Habit: The Case of Online Group-Buying in Taiwan." International Journal of Information Management $35: 45-56$.
Humphrey, J., and H. Schmitz. 1998. "Trust and Inter-firm Relations in Developing and Transition Economies." Journal of Development Studies 34 (4): 32-61.

Ip, C., R. Law, and H. A. Lee. 2011. "A Review of Website Evaluation Studies in the Tourism and Hospitality Fields from 1996 to 2009." International Journal of Tourism Research 13 (3): 234-65.

Jai, T. M., L. D. Burns, and N. J. King. 2013. "The Effect of Behavioural Tracking Practices on Consumers' Shopping Evaluations and Repurchase Intention toward Trusted Online Retailers." Computers in Human Behaviour 29:901-9.

Jarvenpaa, S., and P. A. Todd. 1997. "Consumer Reactions to Electronic Shopping on the World Wide Web." International Journal of Electronic Commerce 1 (Winter): 59-88.

Jarvenpaa, S. L., N. Tractinsky, and M. Vitale. 2000. "Consumer Trust in an Internet Store." Information Technology and Management 1 (1/2): 45-71.

Jensen, J. M. 2012. "Shopping Orientation and Online Travel Shopping: The Role of Travel Experience." International Journal of Tourism Research 14 (1): 56-70.

Joo, J., and Y. Sang. 2013. “Exploring Koreans' Smartphone Usage: An Integrated Model of the Technology Acceptance Model and Uses and Gratifications Theory." Computers in Human Behavior 29 (6): 2512-18.

Josang, A., R. Ismail, and C. Boyd. 2007. "A Survey of Trust and Reputation Systems for Online Service Provision.” Decision Support Systems 43:618-44.

Kamarulzaman, Y. 2007. "Adoption of Travel E-shopping in the UK." International Journal of Retail \& Distribution Management 35 (9): 703-19.

Kim, D. J., D. L. Ferrin, and H. R. Rao. 2008. "A Trust-Based Consumer Decision-Making Model in Electronic Commerce: The Role of Trust, Perceived Risk, and Their Antecedents." Decision Support Systems 44 (2): 544-64.

Kim, D. J., Y. I. Song, S. B. Braynov, and H. R. Rao. 2005. "A Multidimensional Trust Formation Model in B-to-C E-commerce: A Conceptual Framework and Content Analyses of Academia/Practitioner Perspectives." Decision Support Systems 40 (2): 143-65.

Kim, H. B., T. Kim, and S. W. Shin. 2009. "Modeling Roles of Subjective Norms and eTrust in Customers' Acceptance of Airline B2C E-commerce Websites." Tourism Management 30:266-77.

Kim, H. W., Y. Xu, and S. Gupta. 2012. "Which Is More Important in Internet Shopping, Perceived Price or Trust?" Electronic Commerce Research and Applications 11 (3): 241-52.

Kim, H. W., Y. Xu, and J. Koh. 2004. "A Comparison of Online Trust Building Factors between Potential Customers and Repeat Customers." Journal of the Association for Information Systems 5 (10): 392-420.

Kim, J., A. Fiore, and H. Lee. 2007. "Influence of Online Store Perception, Shopping Enjoyment, and Shopping Involvement on Consumer Patronage Behaviour towards an Online Retailer." Journal of Retailing and Consumer Services 14:95-107.

Kim, L. H., H. Qu, and D. J. Kim. 2009. "A Study of Perceived Risk and Risk Reduction of Purchasing Air-Tickets Online." Journal of Travel \& Tourism Marketing 26 (3): 203-24.

Kim, M., and J. Ahn. 2006. "Comparison of Trust Sources of an Online Market-Maker in the E-marketplace: Buyer's and 
Seller's Perspectives." Journal of Computer Information Systems 47 (1): 84-94.

Kim, M. J., N. Chung, and C. K. Lee. 2011. "The Effect of Perceived Trust on Electronic Commerce: Shopping Online for Tourism Products and Services in South Korea." Tourism Management 32 (2): 256-65.

Kim, M. J., C. K. Lee, N. Chung, and W. G. Kim. 2014. "Factors Affecting Online Tourism Group Buying and the Moderating Role of Loyalty." Journal of Travel Research 53 (3): 380-94.

Koufaris, M., and W. Hampton-Sosa. 2004. "The Development of Initial Trust in an Online Company by New Customers." Information \& Management 41:377-97.

Ku, E. C. 2012. "Beyond Price: How Does Trust Encourage Online Group's Buying Intention.” Internet Research 22 (5): 569-90.

LaRose, R., and N. Rifon, 2007. "Promoting i-safety: Effects of Privacy Warnings and Privacy Seals on Risk Assessment and Online Privacy Behavior." Journal of Consumer Affairs 41 (1): 127-149.

Law, R., R. Leung, and D. Buhalis. 2009. "Information Technology Applications in Hospitality and Tourism: A Review of Publications from 2005 to 2007." Journal of Travel \& Tourism Marketing 26 (5/6): 599-623.

Law, R., and J. Wong. 2003. "Successful Factors for a Travel Website: Perceptions of Online Purchasers in Hong Kong." Journal of Hospitality \& Tourism Research 27 (1): 118-24.

Lee, J., and A. M. Morrison. 2010. "A Comparative Study of Web Site Performance." Journal of Hospitality and Tourism Technology 1 (1): 50-67.

Lee, M. K., and E. Turban. 2006. "A Trust Model for Consumer Internet Shopping." International Journal of Electronic Commerce 6 (1): 75-91.

Liang, H., N. Saraf, Q. Hu, and Y. Xue. 2007. "Assimilation of Enterprise Systems: The Effect of Institutional Pressures and the Mediating Role of Top Management." MIS Quarterly 31 (1): 59-87.

Li-Ming, A. K., and T. B. Wai. 2013. "Exploring Consumers' Attitudes and Behaviours toward Online Hotel Room Reservations." American Journal of Economics 3 (5C): 6-11.

Lin, H. F. 2007. "Predicting Consumer Intentions to Shop Online: An Empirical Test of Competing Theories." Electronic Commerce Research and Applications 6 (4): 433-42.

Liu, J. N., and E. Y. Zhang. 2014. "An Investigation of Factors Affecting Customer Selection of Online Hotelbooking Channels." International Journal of Hospitality Management 39:71-83.

Llach, J., F. Mariomon, and M. Alonso-Almeida. 2013. "Determinants of Online Booking Loyalties for the Purchasing of Airline Tickets." Tourism Management 35 (April): 23-31.

Macintosh, G., and L. S. Lockshin. 1997. "Retail Relationships and Store Loyalty: A Multi-level Perspective." International Journal of Research in Marketing 14 (5): 487-97.

Magnusson, P., Stanford A. Westjohn, Alexey V. Semenov, Arilova A. Randrianasolo, and Srdan Zdravkovic. 2013. "The Role of Cultural Intelligence in Marketing Adaptation and Export Performance." Journal of International Marketing 21 (4): 44-61.

Mayer, R. C., J. H. Davis, and F. D. Schoorman. 1995. "An Integrative Model of Organization Trust." Academy of Management Review 20 (3): 709-34.
McCoy, S. D., D. F. Galletta, and W. R. King. 2007. "Applying TAM across Cultures: The Need for Caution." European Journal of Information Systems 16 (1): 81-90.

Mcknight, D. H., and N. L. Chervany. 2001. "What Trust Means in E-commerce Customer Relationships: An Interdisciplinary Conceptual Typology." International Journal of Electronic Commerce 6 (2): 35-59.

McKnight, D. H., V. Choudhury, and C. Kacmar. 2002. "The Impact of Initial Consumer Trust on Intentions to Transact with a Web Site: A Trust Building Model." Journal of Strategic Information Systems 11 (3-4): 297-323.

Moital, M., R. Vaughan, and J. Edwards. 2009. "Using Involvement for Segmenting the Adoption of E-commerce in Travel." The Service Industries Journal 29 (5): 723-39.

Molla, A., and P. Licker. 2005. "Ecommerce Adoption in Developing Countries: A Model and Instrument." Information and Management 42:877-99.

Moore, G. C., and I. Benbasat. 1991. "Development of an Instrument to Measure the Perceptions of Adopting an Information Technology Innovation." Information Systems Research 3 (2): 192-222.

Morakabati, H. 2007. "Tourism, Travel Risk and Travel Risk Perceptions: A Study of Travel Risk Perceptions and the Effects of Incidents on Tourism." PhD diss., Bournemouth University, Dorset, United Kingdom.

Morosan, C. 2012. "Theoretical and Empirical Considerations of Guests' Perceptions of Biometric Systems in Hotels: Extending the Technology Acceptance Model." Journal of Hospitality \& Tourism Research 36 (1): 52-84.

Moyano, F., C. Fernandez-Gago, and J. Lopez. 2012. “A Conceptual Framework for Trust Models." In Trust, Privacy and Security in Digital Business 2012, LNCS 7449, edited by S. FischerHübner, S. Katsikas, and G. Quirchmayr, 9. Berlin Heidelberg: Springer.

Mukherjee, A., and P. Nath. 2007. "Role of Electronic Trust in Online Retailing: A Re-examination of the Commitment-Trust Theory." European Journal of Marketing 41 (9/10): 1173-1202.

National Retail Federation. 2007. "Spending on Dorm Furnishings, Electronics Drives Back-to College Sales Past $\$ 31$ Billion." Retrieved from http://www.nrf.com/modules. php?name $=$ News\&op=viewlive\&sp_id $=354$

Nunnally, J., and I. H. Bernstein. 1994. Psychometric Theory, 3rd ed. London: McGraw-Hill.

Palvia, P. 2009. "The Role of Trust in E-commerce Relational Exchange: A Unified Model." Information and Management 46 (4): 213-20.

Park, C. 2010. "A Literature Review on Online Consumer Behavior in Korea." Journal of Consumer Studies 21 (2): 289-320.

Pavlou, P. A., and M. Fygenson. 2006. "Understanding and Predicting Electronic Commerce Adoption: An Extension of the Theory of Planned Behavior." MIS Quarterly 30 (1): 115-43.

Podsakoff, P. M., S. B. MacKenzie, J. Y. Lee, and N. P. Podsakoff. 2003. "Common Method Biases in Behavioral Research: A Critical Review of the Literature and Recommended Remedies." Journal of Applied Psychology 88 (5): 879-903.

Ponte, E. B., E. Carvajal-Trujill, and T. Escobar-Rodr. 2015. "Influence of Trust and Perceived Value on the Intention to Purchase Travel Online: Integrating the Effects of Assurance on Trust Antecedents." Tourism Management 47:286-302. 
Richardson, S. A. 2009. “Undergraduates' Perceptions of Tourism and Hospitality as a Career Choice." International Journal of Hospitality Management 28 (3): 382-8.

Ren, Z., and T. M. Hassan. 2008. "Trust in E-commerce." In E-business in Construction, edited by C. J. Anumba and K. Ruikar, 195-210. Oxford, UK: Wiley-Blackwell.

Roldán, J. L., and M. J. Sánchez-Franco. 2012. "Variance-Based Structural Equation Modelling: Guidelines for Using Partial Least Squares in Information Systems Research." In Research Methodologies, Innovations and Philosophies in Software Systems Engineering and Information Systems, edited by M. Mora, 163-221. Hershy, PA: IGI Global.

Salam, A. F., L. Iyer, P. Palvia, and R. Singh. 2005. "Trust in E-commerce." Communications of the ACM 48 (2): 73-77.

San Martín, H., and A. Herrero. 2012. "Influence of the User's Psychological Factor Son the Online Purchase Intention in Rural Tourism: Integrating Innovativeness to the UTAUT Framework.” Tourism Management 33 (2): 341-50.

Sanz-Blas, S., C. Ruiz-Mafe, and P. Perez. 2014. "Key Drivers of Services Website Loyalty." Service Industries Journal 34 (5): 455-75.

Shim, S., M. A. Eastlick, S. L. Lotz, and P. Warringt. 2001. “An Online Prepurchase Intentions Model: The Role of Intention to Search.” Journal of Retailing 77 (3): 397-416.

Smeltzer, L. 1997. "The Meaning and Origin of Trust in BuyerSeller Relationships." International Journal of Purchasing and Materials Management 33 (1): 40-48.

Smith, D., S. Menon, and K. Sivakumar. 2005. "Online Peer and Editorial Recommendations, Recommendations Trust and Choice in Virtual Markets." Journal of Interactive Marketing 19 (3): 15-37.

Statista. 2015. "Worldwide Online Travel Sales Volume from 2010 to 2016 (in Billion U.S. Dollars).” http://www.statista.com/ statistics/247321/forecast-of-worldwide-online-travel-salesvolume.

Straub, D., M. Keil, and W. Brenner. 1997. "Testing the Technology Acceptance Model across Cultures: A Three Country Study." Information and Management 33 (1): 1-11.

Teo, T. S., and J. Liu. 2007. "Consumer Trust in E-commerce in the United States, Singapore and China.” Omega 35:22-38.

Teo, T. S., and Y. Pian. 2003. "A Model for Web Adoption." Information and Management 41 (4): 457-68.

Teo, T. S., S. C. Srivastava, and L. Jiang. 2009. "Trust and Electronic Governmentsuccess: An Empirical Study.” Journal of Management Information Systems 25 (3): 99-132.

Toms, E. G., and A. R. Taves. 2004. "Measuring User Perceptions of Website Reputation." Information Processing and Management 40:291-317.

Tung, F. C., S. C. Chang, and C. M. Chou. 2008. "An Extension of Trust and TAM Model with IDT in the Adoption of the Electronic Logistics Information System in HIS in the Medical Industry." International Journal of Medical Informatics 77:324-35.

US Census Bureau. 2003. "News Release, US Department of Commerce." Washington DC, August 22.

Vermeulen, I. E., and D. Seegers. 2009. "Tried and Tested: The Impact of Online Hotel Reviews on Consumer Consideration." Tourism Management 30 (1): 123-27.
Wang, L., R. Law, B. D. Guillet, K. Hung, and D. K. Fong. 2015. "Impact of Hotel Website Quality on Online Booking Intentions: eTrust as a Mediator." International Journal of Hospitality Management 47:108-15.

Wang, Y., and K. J. Lin. 2008. "Reputation-Oriented Trustworthy Computing in E-commerce Environments." IEEE Internet Computing 12 (4): 55-59.

Westland, C. J. 2010. "Lower Bounds on Sample Size in Structural Equation Modeling." Electronic Commerce Research and Applications 9 (6): 476-87.

Workman, M. 2014. "New Media and the Changing Face of Information Technology Use: The Importance of Task Pursuit, Social Influence, and Experience." Computers in Human Behavior 31:111-17.

Yaobin, L., and Z. Tao. 2007. "A Research of Consumers' Initial Trust in Online Stores in China." Journal of Research and Practice in Information Technology 39 (3): 167-80.

Yang, K. 2012. "Consumer Technology Traits in Determining Mobile Shopping Adoption: An Application of the Extended Theory of Planned Behavior." Journal of Retailing and Consumer Services 19 (5): 484-91.

Yang, Q., C. Pang, L. Liu, D.C. Yen, and J. M. Tarn. 2015. “Exploring Consumer Perceived Risk and Trust for Online Payments: An Empirical Study in China's Younger Generation." Computers in Human Behavior 50: 9-24.

Yoo, B., and N. Donthu. 2001. "Developing a Scale to Measure the Perceived Quality of an Internet Shopping Site (SITEQUAL)." Quarterly Journal of Electronic Commerce 2 (1): 31-47.

Yoo, K. H., and U. Gretzel. 2009. "Comparison of Deceptive and Truthful Travel Reviews." In Information and Communication Technologies in Tourism 2009: Proceedings of the International Conference in Amsterdam, the Netherlands, 2009, edited by W. Hopken, U. Gretzel, and R. Law, 37-48. Vienna, Austria: Springer-Verlag.

Yoon, S. J. 2002. "The Antecedents and Consequences of Trust in Online-Purchase Decisions." Journal of Interactive Marketing 16 (2): 47-63.

Zhang, L., L. L. Wu, and A. S. Mattila. 2016. "Online Reviews: The Role of Information Load and Peripheral Factors." Journal of Travel Research 55 (3): 299-310.

Zhou, Z. 2004. E-commerce and Information Technology in Hospitality and Tourism. Canada: Delmar Learning.

Zhu, D. H., and Y. P. Chan. 2014. "Investigating Consumer Attitude and Intention toward Free Trials of TechnologyBased Services." Computers in Human Behavior 30 (2): 328-34.

\section{Author Biographies}

Gomaa M. Agag joined Plymouth Business School in March 2012. Prior to this he worked in many academic institutions including Menofia University, Egypt, Sadat City University, Egypt. Dr. Agag's publications largely relate to electronic commerce, information systems in developing countries, social networking, international business, tourism management. Dr. Agag has more than 11 journal and conference papers published or accepted for publication in Journal of Business Ethics, Journal of Travel Research, Journal of World Business, and Journal of 
Internet Research. Dr. Agag worked as a consultant for some industrial companies in Egypt.

Ahmed A. El-Masry (PhD, MBA, BBA) is an Associate Professor of Financial Management at Plymouth Business School, UK. His papers appear in Managerial Finance, Journal of Travel Research, international journal of hospitality management, Computers in Human Behaviour, Journal of Operational Research Society, Expert Systems with Application, Cross-Culture Management: International Review, Corporate Ownership and Control,
Maritime Policy and Management, International Journal of Hospitality Management, Computers in Human Behaviour, and Journal of International Financial Markets, Institutions and Money. He is Editor-in-Chief of Journal of International Business and Finance and a member of editorial boards and reviewers for several international journals. $\mathrm{He}$ is a co-editor of "Mobile Information Communication Technologies Adoption in Developing Countries: Effects and Implications" published by IGI Global, 2011. He has been a contributor and Field Editor of the Encyclopaedia in CSR, published by Springer, 2013. 